\title{
Executive Compensation: A New View from a Long-Term Perspective, 1936-2005
}

\author{
Carola Frydman* and Raven E. Saks**
}

We would like to thank George Baker, Edward Glaeser, Claudia Goldin, Caroline Hoxby, Lawrence Katz, and Robert Margo for their advice and encouragement throughout this project. Very helpful comments have also been received from Doug Elmendorf, Eric Hilt, Antoinette Schoar, Dan Sichel, Laura Starks, and seminar participants at the DAE NBER meetings, AEA meetings, AFA meetings, and EHA meetings. We also thank Michael Weisbach (our editor) and two anonymous referees. We thank the staff at the Historical Collections and Danielle Barney of Baker Library for making the data collection possible and Brian Hall and Jeff Liebman for providing us with their data. Yoon Chang, Yao Huang, Michele McAteer, Timothy Schwuchow, James Sigel, and Athanasios Vorvis provided outstanding research assistance. The views in this paper do not necessarily reflect those of the Board of Governors of the Federal Reserve System or its staff.

This work was supported by the Economic History Association; the Multidisciplinary Program in Inequality \& Social Policy at Harvard University; and the National Science Foundation's Doctoral Dissertation Research Grant (0452980).

* M.I.T. Sloan School of Management and NBER. NE25-729, 5 Cambridge Center, Cambridge, MA 02142, telephone: 617-258-8408. frydman@mit.edu. Corresponding author.

** Federal Reserve Board of Governors. raven.e.saks@,frb.gov. 


\begin{abstract}
We analyze the long-run trends in executive compensation using a new dataset of top officers of large firms from 1936 to 2005. The median real value of compensation was remarkably flat from the late 1940 s to the 1970 s, revealing a weak relationship between pay and aggregate firm growth. By contrast, this correlation was much stronger in the past 30 years. This historical perspective also suggests that compensation arrangements have often helped to align managerial incentives with those of shareholders because executive wealth was sensitive to firm performance for most of our sample. These new facts pose a challenge to several common explanations for the rise in executive pay since the $1980 \mathrm{~s}$.
\end{abstract}


The compensation paid to CEOs of large publicly-traded corporations rose dramatically during the 1980s and 1990s, stimulating much debate on the determinants of managerial pay (Murphy, 1999; Hall and Murphy, 2003). The discussion has been largely inconclusive, in part because readily available data only exist for the time period after 1970. By constructing a new long-run time series on executive pay, we are able to consistently document the trends in the level and structure of pay over most of the twentieth century. This historical perspective reveals several new facts that contrast sharply with data from recent decades, allowing us to reassess some of the most popular explanations for the recent surge in compensation.

Although the stylized facts on executive pay since the 1970s are well established, only a handful of studies analyzed managerial compensation prior to that date (Murphy, 1999). ${ }^{1}$ Because these studies use different sample designs and employ different methodologies to value the components of remuneration, they cannot provide a systematic description of how executive compensation evolved over the longer run. Therefore, we present new evidence on the long-run trends in compensation by hand-collecting a panel dataset on the remuneration of individual executives based on proxy statements and 10-K reports from 1936 to 2005. Although our sample is mainly composed of executives employed in the largest corporations in the economy, our results are broadly characteristic of the largest 300 publicly-traded firms.

The data from earlier decades reveal several surprising facts that go against current views of the important determinants of top executive pay. First, executive compensation was remarkably flat from the end of World War II to the mid-1970s, even though firms grew considerably during that time. This result contradicts the prevailing view that total compensation

\footnotetext{
${ }^{1}$ A few examples include Baker (1938), Roberts (1959), Lewellen (1968), and Wattel (1978).
} 
rose significantly from the 1940 s to the 1960 s (Lewellen, 1968). ${ }^{2}$ Moreover, the stability of pay at that time contrasts sharply with the 1980-2005 period, when executive pay and firms expanded at almost the same rate. ${ }^{3}$

A second surprising finding is that the magnitude and determinants of the correlation between executives' wealth and the performance of firms ("pay-to-performance") were similar from the 1930s to the 1980s. Because we observe an executive's holdings of both stock and stock options for our entire sample period, our data provide the first consistently-measured, comprehensive evidence on pay-to-performance over the past 70 years. ${ }^{4}$ The sensitivity of changes in wealth to performance was about the same from the mid-1950s to the mid-1980s (with a small dip in the 1970s), and then strengthened considerably from the mid-1980s to 2005 . Therefore, Jensen and Murphy's (1990) view that CEOs in the 1970s were paid like bureaucrats was not generally true in the past. Although the strength of the incentives provided by these

\footnotetext{
${ }^{2}$ Lewellen (1968), thus far the most commonly-cited and comprehensive historical study on executive pay, finds a large increase in the level of pay during this period. However, his findings overestimate the growth in pay because he overstates the value of several components of pay, including employee stock options. See Section 3.2 and footnote 15 for more details.

${ }^{3}$ Consistent with our findings, Boschen and Smith (1995) note that the level of pay was relatively flat from 1948 to 1970 in a panel of 16 firms in the chemical, aerospace, and electronics industries. However, the representativeness of their sample is not clear because it is limited to three industries (electronics, aerospace, and chemical) and suffers from survivor bias (only firms that existed for the entire period from 1948 to 1990). These particular industries were originally chosen because they were essential for the postwar expansion and, therefore, experienced temporary but intensive technological growth during the early part of their sample period (Masson, 1971).

${ }^{4}$ Other studies on pay-to-performance over the longer run do not take into account the incentives provided by revaluations of stock or stock options holdings (Jensen and Murphy, 1990; Boschen and Smith, 1995; Hadlock and Lumer, 1997).
} 
correlations is difficult to assess, we find that executives' monetary gains for improvements in firm performance were not inconsequentially small for most of our sample period. We also find that the correlations of firm characteristics with pay-to-performance have not changed much over time. Thus, recent decades were not the first period in which compensation arrangements generated a strong link between the executives' wealth and firm value.

A comprehensive analysis of the causes of these trends is beyond the scope of the present paper, but the long-run data provide new evidence that inform some of the major hypotheses for the recent surge in executive compensation. First, the run-up in CEO pay and the expanded use of stock options have been linked to managers' ability to extract rents from the firm (Bebchuk and Fried, 2003; Bebchuk and Fried, 2004; Kuhnen and Zwiebel, 2007). However, both the level of pay and the use of options were lower from the 1950s to the 1970s than they were in more recent years, even though corporate governance does not appear to have been stronger in the past. Moreover, we find that the growth in executive pay cannot be explained by changes in board characteristics, the rise of shareholders who own large blocks of stock, or the decline in family-owned firms.

A second set of explanations relates executive pay to changes in firm size. Firms' competition for scarce managerial talent may lead to higher compensation in larger firms (Lucas, 1978; Rosen, 1981; Rosen, 1982; Tervio, 2008). Extensions of this theory also predict that compensation should rise along with increases in the size of the typical firm in the market (Gabaix and Landier, 2008). Despite the strong correlation between executive compensation and the aggregate market value of firms documented in recent decades (Hall and Murphy, 2003; Jensen, Murphy, and Wruck, 2004; Gabaix and Landier, 2008), we find a much lower correlation 
prior to the mid-1970s. In addition, the strong correlation in more recent decades may be due to an upward trend in both variables instead of a causal effect of firm size on pay.

Third, the high level of pay in recent years has been attributed to the need to compensate executives for the risk generated by a greater use of incentive pay. ${ }^{5}$ Finding evidence to support or reject this hypothesis is difficult because the optimal relationship between incentive pay and the total level of compensation predicted by principal-agent models depends on unobservable parameters. With this caveat in mind, we do not find strong support for risk as an explanation for the rise in the level of pay under the admittedly strong assumption that the unobservable parameters of the model remained constant over time.

Finally, the transformation from firm-specific to general managerial skills might have boosted the level of executive compensation (Murphy and Zábojník, 2004). However, a slow and smooth evolution of skills suggests that this explanation cannot easily account for the sharp change in the trend in pay in the 1970s and the very rapid increases witnessed in the 1990s.

Overall, it seems unlikely that a single explanation can account for the long-run trends that we document in this paper. Although it is possible that combining these explanations might have greater explanatory power, much of our evidence points to a sharp change in the pattern of compensation around the 1970s. Thus, focusing on factors that changed during that time may contribute greatly to understanding the evolution of pay. Several plausible mechanisms for the longer-run changes in pay and in pay-to-performance include the IT revolution and skilledbiased technical change, improvements in board diligence and the disclosure of financial information, and changes in social norms. More generally, further studies of executive

\footnotetext{
${ }^{5}$ The optimal sensitivity of managerial wealth to firm performance may have increased in recent decades due to rising business risk (Inderst and Mueller, 2006) or greater international competition (Cuñat and Guadalupe, 2006).
} 
compensation should address these long-run trends to improve our understanding of the determinants of pay and how they have evolved over time.

\section{Theories of the Determinants of Executive Compensation}

Likely sparked by the surge in executive pay since the mid-1980s, the academic debate has proposed numerous theories addressing the determinants of executive compensation. Since it is not feasible to assess every argument, we focus on the four main economic theories that have been put forth to explain the escalation of executive compensation: managerial rent extraction, the scale of firms, the provision of incentives, and increasing returns to general rather than specific skills. ${ }^{6}$ A challenge of analyzing these theories using only data since the 1980 s is that the level of pay has trended upward in conjunction with many variables reflecting the proposed explanations, making it difficult to rule out unobservable factors that might be driving the coincident trends. Evidence from earlier in the century can shed light on each of these explanations by providing a view of how compensation behaved during periods when the many observable and unobservable factors (such as corporate governance, the scale of firms, and the types of managerial skills) were different. ${ }^{7}$

The first set of theories link executive compensation to managers' ability to extract rents (Bertrand and Mullainathan, 2001; Bebchuk and Fried, 2004; Kuhnen and Zwiebel, 2007). According to this view, poor corporate governance has allowed managers to skim profits from

\footnotetext{
${ }^{6}$ See Kaplan and Rauh (2007) and Gabaix and Landier (2008) for a discussion of the main explanations for the evolution for executive compensation.

${ }^{7}$ While the long-run trends provide useful variation in pay, a disadvantage of using earlier data is that we lack information on many variables that researchers have argued are related to executive pay in recent years, such as the presence of large shareholders, the tenure of CEOs, and detailed measures of the corporate governance of the firm.
} 
the firm, thereby leading to the considerable increase in the level of CEO pay. Since it should be easier for executives to extract rents in forms of remuneration that are more difficult for shareholders to observe or value, this explanation also provides a plausible justification for the recent growth in stock option use. Thus, this hypothesis suggests that the level of pay and the use of forms of remuneration that are easier to conceal (such as stock options) should be higher in periods when corporate governance is weaker.

The second set of explanations relates the level of pay to firm size. Theories of the span of control (Lucas, 1978; Rosen, 1982; Rosen, 1992), superstars (Rosen, 1981), and competitive assignment of CEOs to heterogeneous firms (Tervio, 2008; Gabaix and Landier, 2008) predict a positive cross-sectional correlation between firm size and compensation. Extensions of these models propose that the variation in compensation over time should be positively correlated with increases in aggregate firm size because competition for talented managers raises the equilibrium level of pay when the sizes of all potential employers expand (Gabaix and Landier, 2008). Thus, this view predicts that the level of pay should increase at the same rate as the expansion of aggregate firm size.

A third proposal relates the upward trend in compensation since the 1980 s to the simultaneous rise in incentive pay, since higher remuneration may be necessary to compensate risk-averse executives for a riskier stream of income. In a moral hazard model, fixed pay and incentive pay are both endogenously determined by the model's parameters (i.e., the effort cost, the coefficient of risk aversion, and the noise in the performance measure). In a simple version of this model that assumes a normally distributed performance measure, a constant absolute risk aversion utility function, and a linear wage contract, the ratio of an executive's fixed pay relative 
to incentive pay falls as incentive pay increases. Therefore, we would predict fixed pay to be related to changes in pay-to-performance over time.

Finally, academics have associated the recent rise in compensation to changes in the types of managers. For example, Murphy and Zábojník (2004) argue that CEO pay has risen because of the increasing importance of general managerial skills relative to firm-specific abilities. This explanation suggests that we should observe a higher average and more dispersion of pay across executives as managerial skills become more general.

To inform the debate on executive pay using long-run data, we need consistentlymeasured information on the level and structure of pay, the dispersion of pay across executives, the correlation of pay with firm size, the sensitivity of pay to firm performance, and managerial skills. After introducing our data in Section 2, we present evidence concerning these aspects of executive pay in Sections 3 to 5. In Section 6, we reassess these theories in light of the long-run trends.

\section{Executive Compensation Data}

Since its inception in 1934, the Securities and Exchange Commission (SEC) has required public corporations to disclose the compensation of their top executives in $10-\mathrm{K}$ reports and proxy statements. Using these corporate reports, we construct a panel dataset on executive compensation from 1936 to 1991 . From 1992 to 2005, we use data from Standard \& Poor's Executive Compensation database (ExecuComp), which is also based on proxy statements. Although the SEC's reporting rules have changed over time (most notably in 1942, 1978, 1992, and 2006), the disclosure requirements relating to salaries, bonuses, equity holdings, and stock options (the forms of remuneration that are the main focus of our analysis) provide sufficiently 
detailed information that we can track these measures in a consistent manner over our entire sample period.

To construct our dataset, we select the largest 50 publicly-traded corporations in 1940, 1960 , and $1990 .^{8}$ We identify the largest firms in 1960 and 1990 by ranking corporations in Standard \& Poor's Compustat database according to their total sales. The Compustat data do not extend back to 1940, so for that year we rank firms in the Center for Research in Security Prices (CRSP) database according to their market value. Because some firms appear among the largest 50 in more than one year, our dataset covers a total of 101 companies. For each firm, we collect annual data on the pay of the top officers for as many years as our sources allow. When a firm in our sample merges with a firm outside of the sample, we continue to follow the executives in the merged firm if the new firm retains the same name or if the industrial classification of the new firm does not change. The resulting dataset is an unbalanced panel as companies enter and leave the sample over time. Further details on the sample selection and data measurement can be found in an Appendix posted on our websites, and an abbreviated version of this Appendix follows this paper. We use the term "Full Appendix" to refer to the longer version.

About $75 \%$ of the firms in our sample are in manufacturing industries, but it also contains communications, public utilities, and retail companies. ${ }^{9}$ Table A1 of the Full Appendix lists all

\footnotetext{
${ }^{8}$ Although randomly sampling firms might be preferable for certain aspects of the analysis, the considerable size of the data collection effort and the higher likelihood of finding historical corporate reports for large firms caused us to focus on large firms in three particular years. We chose the years 1940, 1960, and 1990 in order to obtain firms that are large near the beginning, middle, and end of our sample period, which allows our sample to reflect secular changes in industrial composition.

${ }^{9}$ Excluding public utilities, which were highly regulated during much of our sample period, does not alter any of our results.
} 
of the firms in our sample and Full Appendix Table A2 shows the distribution of firms by industry.

By sampling firms that were large at different points in time, our dataset captures some of the structural changes in the economy over this 70 -year period. The sample includes all available years from 1936 to 2005 for each of the selected firms, so it reflects a broader segment of the economy than the largest 50 publicly-traded firms alone (see Full Appendix Table A3). One potential problem with our methodology is that it might over-sample firms that were growing rapidly prior to each of the three selection dates (1940, 1960, and 1990), while regression to the mean could cause a contraction in our sampled firms after these three dates. However, the trends in pay are similar when we separately analyze the firms that were the largest in each of the selection dates, suggesting that these sampling concerns are not driving the trends in our data. In Section 3.6, we discuss the representativeness of our data and conclude that our sample reflects the largest 300 publicly-traded corporations in each year. Thus, the trends in median compensation in our data can be interpreted as describing the evolution of pay at the $150^{\text {th }}$ largest publicly traded firm in the economy.

Table 1 reports basic descriptive statistics of our main sample, which includes the three highest-paid officers in each firm. There are more than 15,800 executive-year observations between the years 1936 to 2005, for a total of 2,862 individuals. These officers were the main decision-makers in the firm, as more than $47 \%$ of these managers held the title "CEO," "president," or "chairman of the board."10 Furthermore, more than $80 \%$ of these officers also served on the board of directors (see Table 2).

\footnotetext{
${ }^{10}$ Because the term "CEO" was not frequently used until the 1970s, identifying who held this position is not always straightforward. Previous studies suggest that this person was most often the president of the company, so we
} 


\section{Long-Run Trends in the Level and Structure of Compensation}

\subsection{Trends in total compensation}

The solid line in Figure 1 shows the median real value of total compensation from 1936 to 2005. ${ }^{11}$ We define total compensation as the sum of salaries, bonuses, long-term incentive payments, and the Black-Scholes value of stock option grants. The figure reveals three distinct phases that form a J-shaped pattern over the course of our sample period. During the first 15 years, the real value of compensation fell from about $\$ 0.9$ million to $\$ 0.75$ million. Although it was more pronounced during World War II, the decline in executive pay continued from the end of the war until the early $1950 \mathrm{~s} .{ }^{12}$ This period of deterioration was followed by 25 years of slow growth, averaging $0.8 \%$ per year from 1950 to 1975 . Finally, the level of executive pay climbed at an increasing rate since the mid-1970s. Although compensation dipped briefly from 2001 to 2003, it resumed a rapid rate of growth during the last two years of our sample. Thus, the rapid increase in pay in the 1990s did not end with the stock market collapse in 2000.

identify the president as the chief executive where the CEO is not explicitly mentioned (Mace, 1971). In cases where we observe neither a CEO nor a president, we identify the chairman of the board as the CEO (about $2 \%$ of the observations). We discuss how our results differ if we focus on CEOs in Section 3.5, and these results are robust to identifying the $\mathrm{CEO}$ as the chairman of the board or the highest-paid officer.

${ }^{11}$ Throughout the paper, real values are measured in year 2000 dollars using the Consumer Price Index.

12 The sharp contraction in pay during the war period could be a manifestation of the compression in income inequality documented by Goldin and Margo (1992) and Piketty and Saez (2003). It is plausible that explicit salary restrictions, as well as implicit pressure from public opinion contributed to the decline in the real value of top incomes during this period. However, war-related restrictions are unlikely to account for why executive pay remained relatively low for the following 30 years. 


\subsection{The structure of executive compensation}

Figure 1 also presents the three main components of total pay. The short dashed line shows the median value of salaries plus any bonus that was both awarded and paid out within the same year, which we refer to as a current bonus. These bonuses were generally paid in cash, but some were also paid in company stock. The long-dashed line adds the amount paid to each executive as part of a deferred bonus or long-term incentive payment. Finally, the solid line adds the Black-Scholes value of stock option grants.

During the first 20 years of our sample, compensation was composed mainly of salaries and current bonuses. While long-term bonuses were used as early as the 1940s, they did not make a noticeable impact on median pay until the 1960s. ${ }^{13}$ These bonuses were usually based on the firm's profits, with payment in cash or stock distributed in equal installments over a certain number of years. Long-term bonuses became a greater share of compensation over timereaching more than $35 \%$ of total pay by 2005 - mostly due to the growing popularity of restricted stock awards.

Stock options also became a larger fraction of compensation over our sample period. The use of employee stock options was almost negligible until 1950, when tax reform legislation introduced the restricted stock option. Taxed as a capital gain instead of as labor income, these options had a considerable tax advantage compared to cash because income tax rates were extremely high. This tax policy had immediate impact, as more than $40 \%$ of the firms in our sample instituted a restricted stock option plan in the five years following this reform. However,

\footnotetext{
${ }^{13}$ The 1940s were not the first period when incentive compensation was used. Historical accounts suggest that both current and deferred forms of incentive pay were almost negligible prior to WWI but became commonly used during the 1920s (Taussig and Barker 1925, Baker, and Crum, 1935). Most bonus plans were abandoned or suspended as profits plummeted during the Great Depression (Baker, 1938).
} 
stock option grants did not materially contribute to the median level of pay at that time because grants were relatively infrequent. Typically only $16 \%$ of executives in a given year were granted options during the $1950 \mathrm{~s} .{ }^{14}$ Starting in the 1980 s, stock options became a greater share of median pay over time as the frequency of grants rose (see Figure 2).

Our findings highlight the importance of measuring compensation consistently over time because previous studies have found a larger role for stock options in the compensation package from the 1950s to the 1970s (Lewellen, 1968; Patton, 1994). For example, Lewellen (1968) reports that the average value of stock option grants rose considerably from 1950 to 1963 , reaching $48 \%$ of total pay of the highest-paid executive in 1963 . However, he measures the value of stock options as the amount of pre-tax labor income needed to give the executive the same after-tax payment as the amount received from the after-tax gains from exercising the options. Because personal income tax rates were significantly higher than the capital gains tax rate that applied to options, this method severely overstates the value of option grants during this period. $^{15}$

\footnotetext{
${ }^{14}$ Among executives receiving an option award, the median value of grants fluctuated between $20 \%$ and $30 \%$ of total pay from the mid-1950s to the mid-1990s before rising to $50 \%$ by 2000 and then falling back to $30 \%$ in the last three years of our sample.

${ }^{15}$ To further understand Lewellen's methodology, consider an option granted with an exercise price of $\$ 1$ with a five-year duration. Assume that the capital gains on the stock when it is eventually sold will be taxed at a $25 \%$ rate (Lewellen actually uses a lower tax rate of $15 \%$ to account for deferral in the tax payment) and that the marginal labor income tax rate is $70 \%$. If the market price of the stock by the end of the first year is $\$ 1.25$, then Lewellen's pre-tax equivalent value of the option in the first year would be $1 / 5$ of the present discounted value of $(\$ 1.25$ $\$ 1)^{*}[(1-0.25) /(1-0.7)]$. If the market price rises to $\$ 1.5$ in the next year, the option's value becomes $1 / 4$ of the present discounted value of $(\$ 1.5-\$ 1.25) *[(1-0.25) /(1-0.7)]$. Thus, Lewellen's methodology overestimates the value of options both because he uses an ex-post value (rather than the grant value) and because the "pre-tax equivalent"
} 


\subsection{Other unobserved forms of compensation}

Our measure of total pay does not include information on pensions and perquisites, and excluding these forms of remuneration might bias the trend in total compensation. Although proxy statements provide descriptions of pension plans, we are unable to estimate their value because most plans are based on information that we lack, such as the age-tenure profile of managers. We exclude perquisites because firms were not required to report this type of pay until the late 1970s. ${ }^{16}$ Because pensions are not taxed until after retirement and perks are not always de facto taxed, these methods of pay may have been disproportionately used in the 1950s and 1960s, when tax rates were high and corporate governance was arguably weaker. ${ }^{17}$ Thus, the growth rate in total pay (including both observed and unobserved forms of compensation) may have been faster during these earlier decades than in later years when the tax advantage of these non-taxable benefits was smaller.

Despite the potential bias, the following back-of-the-envelope calculation suggests that the combined value of pensions, perquisites, and other untaxed private benefits would need to

incorporates tax rates. Most of the difference between Lewellen's valuation and the Black-Scholes value of options is due to his treatment of taxation.

${ }^{16}$ Regulation introduced in 1978 required firms to disclose the total amount of remuneration distributed or accrued in the form of securities or property, insurance benefits or reimbursement, and personal benefits. Perquisites and other personal benefits (above a minimum threshold) have been separately reported since 1993 . However, the accuracy of data on perks is limited, and so most research has focused on whether a certain perk was offered rather than on its actual value (Rajan and Wulf, 2006; Yermack, 2006).

${ }^{17}$ Even though the Internal Revenue Code of 1954 included fringe benefits as taxable income, the IRS was unable to enforce taxes on perquisites because the SEC did not require their disclosure until 1978 (McGahran, 1988). 
have been implausibly large to explain the low growth rate of pay that we observe in the first half of our sample. For the observable types of compensation in our dataset, median pay increased from $\$ 0.74$ million in 1950 to $\$ 0.82$ million in 1970 , an annual average growth rate of $0.5 \%$. By contrast, median pay increased by a factor of 4.4 from 1980 to 2000 . If we assume that the value of unobserved forms of pay was zero in 1950, these unobserved benefits would need to have amounted to $\$ 2.4$ million in 1970 in order to achieve a rate of increase in total compensation similar to the 1980 to 2000 period $(\$ 0.74 * 4.4-\$ 0.82=\$ 2.4$ million). This amount is almost three times higher than the median level of salaries, bonuses, and stock options at that time and strikes us as implausibly large. Moreover, this number underestimates the necessary value of nontaxable benefits in 1970 if the actual level of unobserved benefits was greater than zero in 1950. Thus, while pensions and perks may partly explain the slow growth rate of measured pay during the 1950s and 1960s, it is doubtful that including these benefits would alter our finding of a much lower rate of increase in observable pay during this period relative to later decades. ${ }^{18}$

\subsection{The executive's value of pay}

\footnotetext{
${ }^{18}$ Moreover, the available evidence on pensions suggests that this form of remuneration cannot account for the low rate of growth in executive compensation during the 1950s and 1960s. Lewellen (1968) reports that retirement benefits were $15 \%$ of after-tax total pay from 1950 to 1963 . Because pensions were taxed at a lower rate than labor income, their value relative to total pre-tax pay must have been even lower than $15 \%$. By contrast, Sundaram and Yermack (2006) find increases in the actuarial value of pensions to be about 10\% of total CEO pay from 1996 to 2002, and Bebchuk and Jackson (2005) report that the ratio of executives' retirement benefits to total pay received during their entire service as CEO was $34 \%$ in 2004 . Therefore, pensions were not a higher fraction of total pay in the 1950 s or 1960 s than they are today.
} 
Although we have measured the components of executive pay in a manner that best reflects the cost to the firm in the absence of taxes, the value of that compensation to the executive may be lower due to taxes and risk aversion. Not only did tax rates change considerably during our sample period (Frydman and Molloy, 2009), but also riskier forms of remuneration (such as stock-based pay and contingent pay) became a larger fraction of the compensation package over time. Thus, the value of compensation to the executive might be different than the trend shown in Figure 1.

To assess the effect of taxes, we calculate the after-tax remuneration of each executive by taxing salaries, bonuses, payouts from long-term incentive programs, and exercises of nonqualified stock options at the labor income tax rate, and grants of qualified options at the capital gains tax rate. ${ }^{19}$ The solid lines in Figure 3 show median pre-tax and after-tax total compensation, and the dashed lines show median pre-tax and after-tax compensation excluding options. After-tax pay falls more steeply than pre-tax pay during WWII due to a significant increase in labor income tax rates. Starting in 1964, after-tax pay rises more than pre-tax pay because of the incremental reduction in labor income tax rates over time. On the whole, however, the trends in pre- and after-tax pay are broadly similar. The contribution of stock options to the median level of after-tax pay is also similar to its pre-tax trend. Even though options were taxed at much lower rates than other forms of pay from 1950 to 1970, they were not granted widely enough at that time to affect the median compensation package.

\footnotetext{
${ }^{19} \mathrm{We}$ assume that the executive files jointly with a spouse, declares no other income besides the compensation from his firm, and takes no deductions. To accord with the tax treatment of options, we measure total pay using the grant value of options from 1950 to 1977 and the exercised value in other years.
} 
Assessing the effect of risk aversion on the executive's value of compensation is difficult because it requires information on the executive's utility function, holdings of equity in the firm, and non-firm-related wealth. Using a certainty equivalent approach, Hall and Murphy (2002) show that the executive's value of an option can range between $2 \%$ and $72 \%$ of the BlackScholes value under reasonable assumptions of risk aversion and outside wealth holdings. In spite of the broad range of estimates, their calculations show that the value of total pay to the executives still increased considerably during the 1990s. ${ }^{20}$ Adjusting for risk should have a smaller impact on the level of pay in earlier years when stock-based and performance-based pay were a smaller share of the compensation package. Consequently, we do not think that adjusting for risk would significantly change the long-run trend in pay.

\subsection{Differences among executives}

Given their importance as decision makers, most of the research on executive compensation has concentrated on the chief executive officer. We focus our analysis on a wider group of top executives because the main explanations for the recent increase in executive pay are not specifically related to CEOs but rather apply to all top managers. As shown by Table 3, the ratio of the CEO's total compensation to the average pay of the other two highest-paid officers in the firm was about 1.4 prior to 1980 . The ratio of CEO to other executive pay rose from the $1980 \mathrm{~s}$ to the 2000-2005 period, suggesting that the return to being the main decision-maker has increased in the past 25 years. On the other hand, the level of non-CEO pay also climbed substantially during this period (by more than $6 \%$ per year), and we do not find noticeable

\footnotetext{
${ }^{20}$ In particular, they find that median total pay in S\&P 500 industrial firms increases by "only" $85 \%$ to $100 \%$ from 1992 to 1999 , rather than the $210 \%$ increase using standard valuation methods.
} 
differences in the structure of compensation between CEOs and other executives (Panel B of Table 3). Therefore, the patterns documented in this paper are not specific to CEOs, but characterize the remuneration of top management more generally.

Examining the distribution of compensation both within and across firms, the general trend in pay is similar at the $10^{\text {th }}, 25^{\text {th }}, 50^{\text {th }}, 75^{\text {th }}$, and $90^{\text {th }}$ percentiles of our sample with the exception of two time periods (see Table 3). First, the decrease in the real value of pay in the 1940s was larger at the high end of the distribution. Second, increases in compensation during the past 25 years were more pronounced for higher-paid executives. Whereas the ratio of pay at the $90^{\text {th }}$ to the $50^{\text {th }}$ percentile fluctuated between 1.8 and 2.4 from 1936 to 1980 , this gap had risen to more than 3.5 by 2005 . Thus, the dispersion of pay across executives remained fairly constant for several decades after WWII and then began to fan out after the 1970s.

\subsection{Representativeness of the sample}

Although the trends in pay are roughly similar for all of the executives in our sample, it is not clear a priori how well our sample reflects the compensation of top officers in the economy more generally. For one reason, pay tends to be higher in larger firms (Roberts, 1956; Kostiuk, 1990; Rosen, 1992). In addition, our sample may not reflect compensation at the largest firms in time periods that are not close to 1940,1960 , or 1990 - the years in which the firms in our sample were among the largest in the economy. Categorizing firms by size, the trends in median total pay were similar in the larger and smaller firms in our sample (see Figure 4). This similarity suggests that the bias in our sample from selecting relatively large firms may not be too important. 
We evaluate the representativeness of our sample in more detail in Section 4 of the Full Appendix, and highlight the main results of that analysis here. Comparing the level of salaries and bonuses from 1970 to 2005 in our sample to pay in similar-sized firms from other more representative datasets, we find that our data are similar to firms that are among the largest 300 in the economy (Full Appendix Section 4.1). No comprehensive datasets on executive pay exist for the period prior to 1970 , so we assign a weight to each firm that is inversely proportional to its probability of being selected among the 500 largest publicly-held firms in each year. The unweighted median level of salary+bonus in our entire sample closely matches the weighted median of the largest 300 firms in the economy. We reach a similar conclusion for the level of total compensation (Full Appendix Sections 2.3, 4.2, and 4.3).

While there are no large-scale datasets on executive pay prior to the 1980 s, we can compare our findings to the handful of studies that have looked at pay during earlier decades. The flat level of salaries and bonuses from the 1940s to the 1970s is consistent with the trends shown in the few other studies with data covering this period (Lewellen, 1968; Wattel, 1978; and Boschen and Smith, 1995). However, these studies disagree on the trends in total compensation. Lewellen (1968) documents a rapid rise in total compensation from 1945 to 1963 mostly because his analysis severely overstates the value of several components of pay, such as employee stock options (see Section 3.2 for an explanation on his methodology). In contrast, Boschen and Smith—who use the Black-Scholes formula to value stock option grants like we do-find that the level of total compensation was relatively flat from 1948 to 1970 . However, the representativeness of their sample is questionable because it is limited to 16 firms in three industries that were selected for their rapid growth in the post-war years and subject to survivorship bias (see footnote 3 for details). Thus, our findings are in line with previous work 
for cash compensation, while we improve the long-run view of total pay by providing consistent and representative estimates of total pay during earlier decades.

\section{The Relationship between Executive Pay and Firm Size}

As discussed in Section 1, theories of competitive assignment of CEOs to heterogeneous firms predict that the level of pay should increase at the same rate as the expansion of aggregate firm size (Gabaix and Landier, 2008). This hypothesis has been sparked by the trends in pay in recent decades, but the relationship between compensation and the market value of firms has not always been as strong as it was in the past 25 years (see Figure 5). Aggregate market capitalization (measured by the S\&P 500 index) increased considerably during the 1950s and 1960s, while the level of pay experienced little change. ${ }^{21}$ To better understand this relationship, Table 4 decomposes the correlation of compensation and firm size in the previous year into three main components: average firm size (reflecting the size of a typical firm in the market), average size of each firm across all years (reflecting firm-specific factors), and the difference of firm size from these year-specific and firm-specific averages (reflecting transitory changes in firm size that are unrelated to market-wide fluctuations). We estimate the correlation between each of these factors and the compensation of each executive in our sample from the following OLS regression:

$$
\operatorname{Ln}\left(\text { Compensation }_{i j t}\right)=\beta_{0}+\beta_{1} \operatorname{Ln}\left(\overline{S_{t-1}}\right)+\beta_{2} \operatorname{Ln}\left(\overline{S_{j}}\right)+\beta_{3}\left[\operatorname{Ln}\left(S_{j t-1}\right)-\operatorname{Ln}\left(\overline{\left.S_{t-1}\right)}-\operatorname{Ln}\left(\overline{S_{j}}\right)\right]+\varepsilon_{i j t},\right.
$$

where $S_{j t-1}$ is firm $j$ 's size in year $t-1, \overline{S_{t-1}}$ is the average size across all firms in our sample in year $t-1$, and $\overline{S_{j}}$ is the average size of firm $j$ across all years. We measure firm size using the

\footnotetext{
${ }^{21}$ The value of stock options and, therefore, of total pay is not mechanically correlated with the market value of the firm because we calculate the value of options granted using the Black-Scholes formula for the entire sample.
} 
firm's market value and break the sample into two periods in order to examine how these correlations have changed over time. ${ }^{22}$

The firm-specific and idiosyncratic components of firm size had a positive and significant effect on compensation over the entire sample period; the coefficients are about 0.2 and did not vary noticeably across periods. ${ }^{23}$ However, the role of aggregate market value has changed markedly over time. During the second half of our sample, the relationship between executive pay and the average market value of firms was roughly 1-for-1 (column 3 of Table 4), similar to the effects reported by Gabaix and Landier (2008) for 1992 to 2004 . However, we estimate a much smaller coefficient of 0.1 in the first 40 years of our sample (column 1 of Table 4). This result cannot be explained by unusual factors related to the Great Depression or World War II, as we find a similarly small coefficient for the period 1946 to 1975 (column 2 of Table 4). Thus, a contribution of our new dataset on historical pay is to show that the relationship between aggregate firm size and the level of executive pay has changed significantly over time.

The bracketed values in Table 4 report the fraction of the variance in compensation that can be accounted for by each of the independent variables. ${ }^{24}$ The firm-specific component of

\footnotetext{
${ }^{22}$ We use the average across firms to represent aggregate market size because it fits easily into a variance decomposition framework. However, our results are robust to using other proxies for aggregate market size including the median market value in our sample, average and median market value in the largest 500 publiclytraded firms, and the S\&P index.

${ }^{23}$ This cross-sectional correlation is consistent with numerous other studies including Roberts (1956), Lewellen (1968), Murphy (1985), and Kostiuk (1989).

${ }^{24}$ These results are based on an ANOVA decomposition for each sample period. The fraction of the variance explained by each independent variable is the sum of squared residuals explained by that variable relative to the total sum of squared residuals of $\ln ($ compensation).
} 
size explains between $13 \%$ and $17 \%$ of this variation in both periods, while idiosyncratic shocks to firm size account for another 3 to 4 percent. By contrast, the importance of aggregate firm size has changed substantially: it explains $34 \%$ of the variation in pay from 1976 to 2005, but only $2 \%$ in the first half of our sample. Our results are robust to using firm fixed effects to control for firm-specific factors in a more flexible way (Panel 2 of Table 4). Thus, the crosssectional relationship between firm size and executive pay has remained relatively stable over the past 70 years, while upward and downward shifts in the distribution of firm size have only affected the level of compensation more recently. ${ }^{25}$

One reason for the change in the relationship between compensation and firm size could be that the level of pay is currently tied to contemporaneous fluctuations in firm size, whereas it was more responsive to lagged firm size in the past. ${ }^{26}$ Panel 3 of Table 4 shows little support for this conjecture. Although the average market value in year $t-2$ had a larger effect on compensation than the year $t-1$ value during the earlier sample period, the sum of these two coefficients is still considerably smaller than the corresponding sum in recent years. Another possible explanation for the change in the correlation is that the relevant measure of firm size has changed over time. However, our results are robust to using the value of sales instead of market value (columns 4 and 5 of Table 4).

\footnotetext{
${ }^{25}$ In fact, the strong correlation between compensation and aggregate firm size was limited to the 1980s and 1990s. For all other decades in our sample, average market value accounts for less than $1 \%$ of the variation in executive pay (see Full Appendix Table A6).

${ }^{26}$ For example, this difference in timing would result from switching from accounting-based to market-based measures of firm performance when determining incentive pay.
} 
One interpretation of these results is that aggregate firm size became a key determinant of executive pay during the past 30 years, whereas it was not important in previous decades. ${ }^{27}$ However, the estimated coefficients may be spuriously driven by upward trends in firm size and the level of compensation. Indeed, adding a quadratic time trend to the regression reduces the coefficient on average market value somewhat and makes the coefficient on aggregate sales negative (Panel 4 of Table 4). Moreover, tests for non-stationarity cannot reject the null hypothesis that there is a unit root in the residuals of Equation (1) in either period. ${ }^{28}$ To further address this concern, we estimate the relationship between changes in compensation and changes in firm size (Panel 5 of Table 4). The estimated effect of the average size of the market is notably smaller in this specification, and it explains a much smaller fraction of the variance in changes in pay than the corresponding specification in levels. ${ }^{29}$ Thus, the seemingly-strong correlation between average firm size and the level of pay of the past several decades may be driven by upward trends in both variables rather than the result of a true causal effect.

\footnotetext{
${ }^{27}$ Another possible explanation for this result is that our estimated coefficients in the earlier period may be biased downwards if pensions and perks were higher during this time. However, an exercise similar to our back-of-the envelope calculation in Section 3.3 suggests that this explanation is unlikely. If the growth rate of total compensation has a one-to-one correlation with aggregate firm size (as we find for the recent period), the level of pay should have increased by a factor of 3.3 from 1950 to 1968 . In this case, unobserved forms of pay would need to have amounted to $\$ 1.6$ million by 1968 , an improbably high level of pensions, perks, and other private benefits.

${ }^{28}$ Using Pesaran's (2007) panel unit root test, the null hypothesis of non-stationarity in the residuals of the second period has a p-value of 0.59. Therefore the presence of a unit root in the residuals cannot be ruled out. The corresponding $\mathrm{p}$-value for the residuals in the early period is 0.01 , suggesting that there is less likely to be a trend in the residuals in the first half of the sample.

${ }^{29}$ Evidence from both Hall and Liebman's 1980-1994 and ExecuComp's 1992-2005 datasets confirms this result in these alternative samples. Details available upon request.
} 


\section{The Evolution of Pay-to-Performance Over Time 5.1 Defining measures of pay-to-performance}

Managerial decisions can be influenced by changes in any form of the executive's wealth that is tied to the performance of the firm. Therefore, a comprehensive measure of pay-to-performance should include the remuneration awarded to the executive plus the revaluations of his stock and stock option holdings (Jensen and Murphy, 1990; Hall and Liebman, 1998). ${ }^{30}$

Empirical studies of pay-to-performance have used a wide range of specifications to measure this relationship. ${ }^{31}$ Two common alternatives are the dollar change in executive wealth per dollar change in firm value (the Jensen-Murphy statistic), and the dollar amount of wealth that an executive has at risk for a $1 \%$ change in the firm's value (the value of equity at stake). ${ }^{32}$ In a simple agency model that allows the marginal product of managerial effort to vary with the value (or size) of the firm, the optimal level of effort (that is, the optimal strength of managerial incentives) depends on the type of CEO activity being considered (Baker and Hall, 2004). The Jensen-Murphy statistic is the correct measure of incentives for activities whose dollar impact is

\footnotetext{
${ }^{30}$ A limitation of our data is the lack of information on forms of wealth and earnings that are not related to compensation, such as dividends, capital gains, and non-firm related wealth. We use the term "wealth" to refer to firm-related wealth.

${ }^{31}$ For a discussion of the statistics, see Jensen and Murphy (1990), Joskow and Rose (1994), Garen (1994), Hall and Liebman (1998), Murphy (1999), Aggarwall and Samwick (1999), Baker and Hall (2004), and Edmans, Gabaix and Landier (2008).

${ }^{32}$ Both of these statistics give an empirical measure of the correlation between pay and firm performance. While a higher pay-to-performance sensitivity will likely influence managerial actions, this correlation is not necessarily caused by firms' desire to provide incentives. For example, the association between pay and firm performance can also be the result of a bargaining or fairness model (Blanchflower, Oswald, and Sanfey, 1996; Benjamin, 2005).
} 
the same regardless of the size of the firm and the value of equity at stake is appropriate for actions whose value scales with firm size.

Studies that ignore revaluations of equity and option holdings often also report the elasticity of pay to performance (i.e., percentage change in compensation for a $1 \%$ change in firm value). ${ }^{33}$ An advantage of the elasticity is that it is not highly sensitive to firm size, unlike the other two measures we consider. However, empirical estimates of this measure may be biased because we only observe firm-related wealth. ${ }^{34}$ More importantly, this measure will be close to one when only considering the revaluations in stock and stock option holdings as sources of change in wealth. ${ }^{35}$ Therefore, we focus on the Jensen-Murphy statistic and the value of equity at stake, but we return to this issue in Section 5.5 by calculating the elasticity of changes in wealth to firm performance.

\subsection{Trends in stock, stock option ownership, and pay-to-performance}

In recent decades, the sensitivity of pay to performance has been driven by revaluations in stock and stock option holdings (Hall and Liebman, 1998). Therefore, we start by documenting the

\footnotetext{
${ }^{33}$ A log-log functional form for incentives can be obtained theoretically as the optimal contract if utility is CRRA (Himmelberg and Hubbard, 2000) or from a model that embeds incentive pay in a competitive labor market (Edmans, Gabaix, and Landier, 2007).

${ }^{34}$ If non-firm-related assets trended monotonically over time, ignoring forms of wealth not related to the firm would lead to a systematic bias in our estimates of the level and, consequently, of the percentage change in total wealth.

${ }^{35}$ When only equity is considered, this measure will mechanically be equal to zero for executives not holding stocks and equal to one for individuals holding at least one share. For stock options, the percentage change in wealth would be equal to the "delta" (usually smaller than one) of the option for those executives with a positive holding of options.
} 
long-run trends in stock and stock option ownership. To our knowledge, no other studies have examined the evolution of both of these trends over time prior to the 1980s.

Stock option holdings became a major component of wealth in the 1960s, when more than $60 \%$ of the executives in our sample held options (Figure 2). ${ }^{36}$ The use of options has become even more widespread over time; since 1990 more than $90 \%$ of the executives in our sample held options. Moreover, the number of stock options held by top executives rose considerably from 1980 to 2000 relative to the number of shares outstanding. By contrast, equity holdings have declined over the century relative to the firm's total number of shares outstanding, with most of the contraction occurring during WWII (see Table 5). By 2005, median fractional stock holdings were about one-third of their pre-war level. ${ }^{37}$

Following Core and Guay (2002), Table 6 shows the ex-ante change in each executive's stock and stock option holdings in response to a $\$ 1000$ (Jensen-Murphy) or 1\% (equity-at-stake) increase in market value (columns 1 to 4$){ }^{38}$ The ex-ante gains related to changes in stock holdings have been important for our entire sample period. Meanwhile, the ex-ante gains from

${ }^{36}$ The fraction of executives receiving stock options was much smaller than the fraction of executives holding options during this period because options had a long duration and vested slowly over time.

${ }^{37}$ These results differ from Holderness, Kroszner, and Sheehan (1999), who find higher stock ownership in 1995 than in 1935. There are two main explanations for this discrepancy. First, the increase in fractional holdings in their sample does not occur among the largest publicly-held firms, which are more comparable to our sample of firms. In addition, they focus on the holdings of all top officers and directors. When they restrict the sample to CEOs, they find a similar decline in ownership.

${ }^{38}$ The ex-ante revaluation of option holdings is calculated using data on the number and characteristics of each option held in an individual's portfolio and the derivative of the Black-Scholes formula with respect to a $1 \%$ or $\$ 1000$ change in market value [Core and Guay’s (2002) “delta” measure]. 
option holdings increased steadily since the 1950s, and have exceeded the gains due to changes in stock holdings since the 1990s.

Many recent studies have measured incentives as the sum of the ex-ante revaluations of stock and option holdings, which implicitly assumes that the correlation of firm performance with salaries, bonuses, and other forms of compensation is negligible (Coles, Daniel, and Naveen, 2006; Bergstresser and Philippon, 2006). Although this assumption is accurate for the post-1980 period (Hall and Liebman, 1998), it is possible that incentives were provided through changes in compensation in the past (Jensen and Murphy, 1990). Despite this possibility, we find a very low correlation between total pay (defined as salary+bonus+long-term incentive pay+stock option grants) and firm performance throughout our sample period (results available upon request). ${ }^{39}$ Therefore, we use the ex-ante revaluations of stock and stock option holdings to measure pay-to-performance throughout our analysis.

Columns 5 and 6 of Table 6 combine executives' holdings of stock and stock options to show the complete response of wealth to changes in firm performance. In accordance with prior research, both the Jensen-Murphy statistic and the value of equity at stake show a large increase in pay-to-performance during the 1980s and 1990s (Hall and Liebman, 1998; Murphy, 1999). However, these two measures present different views of the longer-run evolution of pay-toperformance: The value of equity at stake was 12 times higher in the 2000-2005 period than it had been in the 1936-1940 period, whereas the Jensen-Murphy statistic had not even recovered its pre-war level by the end of our sample period. The trends in pay-to-performance are similar for both CEOs and other top executives.

\footnotetext{
${ }^{39}$ Moreover, our results are robust to calculating the ex-post sensitivity of pay-to-performance by estimating a regression of the change in executive wealth on changes in firm performance.
} 


\subsection{Accounting for changes in the size of firms over time}

Because the two measures of pay-to-performance have opposite correlations with firm size (Schaeffer, 1998; Baker and Hall, 2004; Edmans, Gabaix and Landier, 2007), the significant increase in firm size over time might explain the divergence in these two statistics prior to the 1980s. ${ }^{40}$ For example, Jensen and Murphy (1990) argue that the Jensen-Murphy statistic was higher in the 1930s than in the 1970s, but Hadlock and Lumer (1997) show that this statistic was similar for large firms in these two periods once they control for firm size.

To correct the long-run trends in pay-to-performance for the secular increase in firm size, we regress each statistic on firm size and year indicators in a series of overlapping four-year sample periods (1936-1939, 1938-1941, etc). ${ }^{41}$ For example, for 1936 to 1939 we estimate:

$$
\begin{aligned}
P P S_{i j t}= & \alpha+\delta I_{t}^{38-39}+\beta_{1} \text { FirmSize }_{j t}^{20 t h-40 \text { th }}+\beta_{2} \text { FirmSize }_{j t}^{40 \text { th-60th }}+\beta_{3} \text { FirmSize }_{j t}^{60 t h-80 \text { th }} \\
& +\beta_{4} \text { FirmSize }_{j t}^{80 t h-100 \text { th }}+\varepsilon_{i j t},
\end{aligned}
$$

where FirmSize ${ }_{j t}^{x x h-y y t h}$ indicates that market value is between the $x x$ th and yyth percentiles of the firm size distribution in the 1936-1939 period, and $I_{t}^{39-40}$ indicates observations in 1938 and $1939 .{ }^{42}$ The year indicator variable in each regression shows how pay-to-performance changed

${ }^{40}$ On the other hand, both measures rose from the 1970 s to the 2000 s despite further increases in firm size, suggesting that pay-to-performance strengthened enough during the past thirty years to offset the downward effect of expanding firm size on the Jensen-Murphy statistic.

${ }^{41}$ We estimate two-year growth rates from four-year sample periods instead of one-year growth rates from two-year sample periods in order to increase the sample size of each regression. Results are similar-but noisier-when using two-year sample periods.

${ }^{42}$ This regression is similar in spirit to Hadlock and Lumer (1997), although we use a non-parametric method to control for firm size and we use ex-ante measures of pay-for-performance rather than estimating the correlation of 
from the first half to the second half of the four-year period holding firm size constant. For example, in the equity at stake regression from 1996 to 1999, the coefficient on the 1998-1999 indicator is 33,412 (s.e. 9,701). The actual increase in equity at stake in this four-year period was $\$ 75,000$, so adjusting for firm size reduces the estimated increase in pay-to-performance by half. ${ }^{43}$ We calculate the size-adjusted growth in pay-to-performance as the change in predicted pay-to-performance from the first half to the second half of each four-year sample period, evaluated at the median firm size of each sample period (see Full Appendix Section 5 for details). ${ }^{44}$ To examine the long-run changes in pay-to-performance, we create indexes that are equal to the median value of pay-to-performance in the 1936-1937 period and use size-adjusted growth rates in pay-to-performance to obtain a new index value in each successive two-year period (see Figure 6).

Adjusted for firm size, pay-to-performance fell noticeably during WWII, but then rose during the 1950s, reaching a level somewhat higher than its initial value by the early $1960 \mathrm{~s}^{45}$ After falling back modestly during the 1970s, it began to trend upward again in the 1980 s. $^{46}$ The

ex-post changes in salaries with firm performance in a regression setup. Our results are unchanged if we specify firm size as $\ln ($ size $)$ instead of the non-parametric approach.

${ }^{43}$ Our estimates of the year indicator variables are significantly negative in the early 1940s and significantly positive in the 1980s and 1990s, but otherwise they are not generally significantly different from zero.

${ }^{44}$ Specifically, the size-adjusted growth rate in each sample period is $\left(\alpha+\delta+\beta_{2}\right) /\left(\alpha+\beta_{2}\right)$.

${ }^{45}$ The sharp drop in pay-to-performance in the early 1940s may be due to a reduction in CEOs ability to affect firms' profits due to the command economy during World War II. It is not clear why these forces would have caused the weak correlation to persist until the end of the decade.

${ }^{46}$ The increase in pay-to-performance since the 1980 s may be due to advances in information technology that increased the productivity of chief executives. As suggested by Holmstrom (1979), firms should provide higher incentive pay when the productivity of managers is higher. 
sensitivity of pay-to-performance accelerated rapidly in recent years, reaching a level three times (Jensen-Murphy) or nine times (equity at stake) higher than its value in the 1930s.

These trends belie the findings of the few prior studies that have assessed the long-run evolution of pay-to-performance. Jensen and Murphy (1990) find that the sensitivity of salaries to performance was an order of magnitude larger in the 1930s than in the 1970s, and Boschen and Smith (1995) find that the elasticity of total compensation to firm performance increased by more than a factor of three from the 1950 s to the 1980 s. However, none of these analyses take into account stock and stock option holdings, the most important component of changes in an executive's wealth.

\subsection{The determinants of pay-to-performance}

Theories based on Holmstrom (1979) suggest that the sensitivity of pay to firm performance depends on firm and industry characteristics such as the degree of informational asymmetries, the presence of direct monitoring mechanisms, the signal-to-noise ratio in the performance measure, and legal rules and institutions that restrict the managerial action space. In this vein, several papers have developed structural models that illustrate how pay-to-performance is determined by primitive characteristics of the firm's production process such as the underlying productivity of physical assets, the marginal product of CEO effort, and the productivity of outside directors (Coles, Lemmon and Meschke, 2002; Coles, Lemmon, and Wang, 2008; and Edmans, Gabaix and Landier, 2007). Thus, the increase in pay-to-performance that we observe in our sample period might signal a change in these underlying characteristics. A growing literature has examined the empirical relevance of a number of proxies for the determinants of pay-to-performance in the 1990s (Bizjak, Brickley and Coles, 1993; Core and Guay, 1999; Smith 
and Watts, 1992), and our paper takes the first look at how these determinants have evolved over the longer run. These correlations should be interpreted with caution, however, because they do not necessarily imply causal effects.

Table 7 reports the results from cross-sectional regressions of the logarithm of equity-atstake on a number of the firm-specific factors considered by previous studies. ${ }^{47}$ We focus on variables that we are able to measure consistently over time and define each variable in Section 3 of the Appendix. Because obtaining many of these variables required extensive data collection, we study the periods 1936-1939, 1950-1959, 1970-1979, and 1990-1999. In general, there are many similarities across these decades. We find a higher sensitivity of compensation to performance in firms with greater growth opportunities (measured as the ratio of market-to-book value $)^{48}$ and a lower correlation between pay and performance in firms that are in regulated industries. $^{49}$ These results are consistent with the findings of some previous studies (Core and Guay, 1990; Smith and Watts, 1992), and give added support to the idea that informational asymmetries and legal rules affect pay-to-performance. ${ }^{50}$ By contrast, Bizjak, Brickley, and

\footnotetext{
${ }^{47}$ Results are similar when using the logarithm of the Jensen-Murphy statistic, except that it has the opposite correlation with firm size, as discussed in Section 5.3.

${ }^{48} \mathrm{We}$ follow the existing literature on the determinants of pay-to-performance by using the market-to-book ratio to proxy for growth opportunities. At the same time, the positive correlation between pay-to-performance and the market-to-book ratio could also reflect higher incentive pay as a reward for strong stock performance. To preclude this possible interpretation, we control directly for stock performance by including the lagged real rate of return.

49 The increase in pay-to-performance in the railroad industry from the 1970s to the 1990s might be related to deregulation that was brought on by the Railroad Revitalization and Regulatory Reform Act of 1976 and the Staggers Rail Act of 1980.

${ }^{50}$ On the other hand, we find no evidence that pay-to-performance was related to information asymmetries when using investment in research and development as an alternative measure of growth opportunities.
} 
Coles (1993) and Yermack (1995) report a negative correlation between pay-to-performance and growth opportunities. Our results suggest that leverage (measured as the ratio of total liabilities relative to total assets), noisiness of the stock price (measured as the standard deviation of idiosyncratic stock-price returns), the firm's rate of return, and the size and composition of the board of directors are not important determinants of pay-to-performance in most decades. ${ }^{51}$

We also find a few interesting differences over time. First, the magnitude of the coefficient on growth opportunities is smaller in the 1990s than in previous decades, possibly because this correlation tends to be smaller in larger firms. In addition, pay-to-performance was positively related to the fraction of inside directors and the size of the board of directors in the 1930s, but this correlation disappears in the postwar period. Since these board characteristics are frequently associated with weaker corporate governance and poor direct monitoring (Jensen, 1993; Yermack, 1996), this result suggests that corporate governance has had a smaller effect on managerial incentives in the postwar period than it did in the $1930 \mathrm{~s} .{ }^{52}$

\subsection{Quantifying the size of the pay-to-performance correlation}

\footnotetext{
${ }^{51}$ For the 1930s and 1990s, the two periods in which we can measure blockholder ownership, we find no effect of greater outside blockholder ownership on the structure of pay or on the sensitivity of pay-to-performance.

${ }^{52}$ Pior studies have found mixed results on the effects of board characteristics on firm outcomes. Moreover, these studies (as well as ours) usually do not address the endogeneity of board characteristics (Hermalin and Weisbach, 2003). Studies analyzing the determinants of board characteristics often find that optimal board size and composition may vary across firms based on factors such as their growth opportunities, size, complexity, and CEO independence (Boone, Karpoff, and Raheja, 2007; Lehn, Patro, and Zhao, 2008; Link, Netter, and Yang, 2008; Coles, Daniel, and Naveen, 2008).
} 
In the standard principal-agent model, the optimal degree of managerial incentives is based on a number of unobservable factors such as the agent's risk aversion and the cost of managerial effort. Therefore, there is no theoretical benchmark of the "optimal" degree of pay-toperformance against which to compare our results (Haubrich, 1994). Nevertheless, we gauge the strength of incentives by calculating an executive's monetary return for a meaningful improvement in firm performance. Following Hall and Liebman (1998), we define a meaningful (albeit modest) improvement in firm performance as a movement from the median rate of return to the $70^{\text {th }}$ percentile rate of return.

To estimate the wealth at stake from this improvement, we calculate the ex-ante dollar change in each executive's stock and option holdings if the firm moved from the median rate of return in our sample $(8.4 \%)$ to the $70^{\text {th }}$ percentile rate of return $(22.7 \%)$. The median change in wealth across executives was over $\$ 1$ million in the 1990 s and 2000 s, but considerably smaller in earlier decades (column 1 of Table 8). However, this upward trend is less noticeable when changes in wealth are compared to a broad measure of compensation that includes salaries, bonuses, stock option grants, and revaluations of stock and options holdings at the median rate of return (column 2 of Table 8). With the exception of the 1940s, a move in firm performance from the $50^{\text {th }}$ to the $70^{\text {th }}$ percentile has typically led to at least a $30 \%$ increase in this broad measure of pay. Thus, it appears that managerial incentives have not been "wildly inefficient" for most of the twentieth century, to paraphrase Hall and Liebman (1998).

Finally, we divide the percent increase in compensation broadly defined (column 2 of Table 8) by the improvement in the rate of return from the median to the $70^{\text {th }}$ percentile of performance. Because the numerator is calculated from changes in wealth, this measure reflects the elasticity of changes in wealth, a concept related to the elasticity of the level of wealth 
discussed in Section 5.1. This elasticity ranged between $1 \frac{1}{2}$ and 4 in most decades, confirming that managerial incentives were not always small prior to the $1980 \mathrm{~s}$.

\section{Re-assessing Theories for the Evolution of Executive Pay}

We do not have exogenous variation in any of the proposed determinants of pay that would allow us to causally identify the relative contribution of each theory for the long-run trends in executive compensation. Nevertheless, the evidence presented in this paper suggests that a number of popular explanations for the recent surge in pay cannot account for the long-run trends on their own.

First, the long-run trends in pay seem inconsistent with explanations related to managerial rent seeking. According to this theory, we should observe higher levels of pay and a higher fraction of pay given in obscure forms of compensation in periods of weak corporate governance. Although measuring corporate governance is not straightforward, we observe lower levels of pay and little use of stock options (which are easier to conceal) earlier in the century, a period in which it has been argued that both external and internal governance mechanisms were weaker (Jensen, 1993; Holmstrom, 2005). ${ }^{53}$

Another aspect of governance that has changed over time is the incidence of familyowned firms. Because the compensation of professional CEOs is lower in family firms, a decline in family ownership could explain the trends in the level of pay (Bates, Jandik and Lehn, 2000; Anderson, Boylan, and Reeb, 2007). Anderson, Boylan, and Reeb (2007) find that CEO

\footnotetext{
${ }^{53}$ Signs that corporate governance was weaker in the past include: proxy fights and takeovers were rare prior to the 1980s (Holmstrom and Kaplan, 2001), boards of directors have become more independent since mid-century (Lehn, Patro, and Zaho, 2008), and both the ownership of institutional shareholders and shareholder activism have increased since the 1950s (Khurana, 2002; Gillian and Starks, 2007).
} 
pay was only $20 \%$ higher in dispersedly-held firms than in family-owned firms in the 2000 s. Consequently, a lower concentration of ownership cannot account for the 8-fold increase in average compensation and 5-fold increase in median compensation that we observe in our sample, even if the fraction of family-owned firms had fallen from $100 \%$ to none.

Our data also suggest that corporate governance did not play a significant role in the rise of executive pay. We consider two types of evidence. The first is the size and composition of the board of directors, since several papers have found that firms with smaller boards and a higher fraction of outside directors tend to make better decisions (Hermalin and Weisbach, 2003). Using board characteristics as a proxy for governance has important limitations because they are a choice of corporations and, therefore, endogenous to firm outcomes (Hermalin and Weisbach, 1998; Harris and Raviv, 2008). With these caveats in mind we investigate whether changes in the log of board size or the fraction of insiders in 1936, 1950, 1970, or 1990 are correlated with the changes in executive pay in the subsequent decade. ${ }^{54}$ We find no statistical association between the fraction of inside directors and the level or the structure of pay in any decade. By contrast, firms with larger boards paid their executives significantly more in the 1930s, 1950s, and 1970s (the magnitude of the correlation is similar in the 1990s, but it is not significantly different from zero). Despite these positive cross-sectional correlations, board size cannot explain the rise in pay over time because it remained constant throughout our sample period.

\footnotetext{
${ }^{54}$ The fraction of insiders in the board is probably underestimated since we lack information on gray directors. The regression for the 1930s uses only data from 1936 to 1939, and all regressions include controls for year indicators, industry, firm size, recent firm performance, noisiness in the performance measure, investment opportunities, leverage, and managerial job titles.
} 
Our second measure of corporate governance is the presence of large outside (non-officer and non-director) shareholders, for which we were able to collect data for the 1930s and 1990s. Outside blockholders may engage in more direct monitoring and, therefore, reduce managers' ability to extract rents. Consistent with prior studies (Mehran, 1995; Core, Holthausen and Larcker, 1999; Hartzell and Starks, 2003), we find that executive pay is curtailed in firms in which outside blockholders own a larger fraction of the equity. ${ }^{55}$ However, the monitoring of large shareholders cannot account for the rise in the level of pay: Average outside blockholder ownership declined from $12 \%$ in the 1930 s to $7 \%$ in the 1990 s, and the magnitude of our coefficient estimates suggests that this decrease should have led to an increase of only $5 \%$ in total compensation.

Clearly, the empirical proxies that we have used to measure corporate governance are imperfect and far from comprehensive. ${ }^{56}$ Nevertheless, none of the evidence that we have found suggests that the ability of executives to set their own pay can explain the dramatic increase in compensation over the century.

Moving on to other hypotheses, our findings suggest that the scale of firms cannot explain the long-run evolution of executive pay. Gabaix and Landier (2008) predict that the

\footnotetext{
${ }^{55}$ These regressions also control for year indicators, industry, firm size, recent firm performance, noisiness in the performance measure, investment opportunities, leverage, and managerial job titles.

${ }^{56}$ Another example related to governance is the growing use of compensation consultants and industry surveys of executive pay, which might have boosted the level of compensation through a "ratcheting effect," (Murphy, 1999; Bizjak, Lemmon and Naveen, 2008). However, compensation consultants may have played a role in determining executive pay as early as the 1950 s, much earlier than the increase in the level of compensation. The American Management Association conducted the first survey of executive compensation designed to help firms set executive pay in 1951, and this annual survey had become an important resource in setting pay by 1960 (Patton, 1961).
} 
time-series evolution in compensation should correlate 1-to-1 with growth in the size of the aggregate value of firms. Although this correlation was present in the past 35 years, it was almost non-existent in earlier decades. Moreover, the strong correlation that characterizes the later period is likely not causal because it appears to be biased by spurious upward trends in the market value of firms and the level of pay.

Another plausible hypothesis is that the growth in executive pay is due to a strengthening of managerial incentives. As described in Section 1, a simple moral hazard model predicts a negative relationship between the ratio of fixed pay to incentive pay and the level of incentive pay. The optimal magnitude of this correlation is difficult to discern because the optimal outcomes from a principal-agent model depend on unobservable factors, such as the executive's risk aversion. Although we cannot provide conclusive evidence, we investigate whether the empirical correlations observed in our sample indicate a link between the level of pay and managerial incentives that can account for the growth in executive pay over time. Under the extreme assumption that the underlying parameters of the principal agent model have not changed over time, we would expect the correlation between these two variables to be stable in our sample period.

Regressing changes in the ratio of fixed pay (defined as salary plus current bonus) relative to pay-to-performance on changes in pay-to-performance, we find a coefficient of about -1 throughout our entire sample period, with no significant change in this coefficient over time. ${ }^{57}$ This cross-sectional correlation indicates that, holding all parameters of the model constant over time, the 8-fold surge in the value of equity-at-stake from 1980 to 2005 should have reduced the

\footnotetext{
${ }^{57}$ Results are similar for both the Jensen-Murphy statistic and the value of equity-at-stake. They are also similar whether or not we adjust changes in pay-to-performance for changes in firm-size.
} 
ratio of fixed pay relative to pay-to-performance by about a factor of 8 . Instead, median salary+bonus relative to the size-adjusted value of equity-at-stake only decreased by a factor of 4. Therefore, fixed pay increased by more from 1980 to 2005 than its empirical correlation with pay-to-performance would suggest. One interpretation of this result is that unobservable parameters of the model—such as the shape of the utility function-have changed over time. A second interpretation is that the rise in pay-to-performance cannot fully account for the rise in the level of pay. The difficulty of observing the parameters of the agency model makes it impossible to distinguish conclusively between these two interpretations. Nevertheless, our results are at least suggestive that the growth in the level of executive pay over time may not be completely explained by a strengthening of managerial incentives.

Finally, our evidence is also hard to reconcile with explanations based on increasing returns to general managerial skills. This theory predicts a positive correlation of the level and dispersion of pay with the degree of generality of managerial skills. Indeed, the level of pay was lower and differences in remuneration across top managers were smaller in the first half of our sample, when abilities of managers were arguably more firm-specific (Frydman, 2005). However, managerial skills have likely evolved smoothly and slowly over time (Frydman, 2005), making it hard to explain the sharp changes in the trends in pay that occurred in the 1970s, as well as the rapid increase in pay since then.

\section{Conclusion}

There have been important changes in the level and the structure of executive pay from 1936 to 2005. The real value of total compensation followed a J-shaped pattern over our sample period. After a sharp decline during World War II, the level of pay increased slowly from the mid-1940s 
to the mid-1970s, and then rose at an increasing rate from the 1970s to the present. The composition of executive compensation also changed considerably since the 1950s, as both stock options and other forms of incentive pay became larger shares of total compensation over time. Using information on executives' stock and option holdings, we find that pay-to-performance sensitivities were considerable in most decades except the 1940s. Thus, compensation arrangements have served to tie the wealth of managers to firm performance- and perhaps to align managerial incentives with shareholders' interests - for most of the twentieth century.

In sum, our data suggest that the post-WWII era can be divided into two distinct periods. Prior to the 1970s we observe low levels of pay, little dispersion across managers, weak correlation between pay and aggregate firm size, and a moderate degree of managerial incentives. Since then, salaries and incentive pay have grown dramatically, differences in pay across executives have widened, the correlation between compensation and aggregate firm size appears to have strengthened, and managerial incentives have gotten stronger. The contrast between these two periods poses a challenge to many explanations for the recent rise in executive pay because the implications of these theories do not hold for the earlier period.

Theories concerning the determinants of pay should address this sharp transformation in executive compensation and why models of pay that appear to fit well in recent decades did not function similarly in the past. One possibility is that the poor performance of firms in the 1970s brought about improved board diligence, thereby making the CEO job less secure (Hermalin, 2005). Similarly, enhanced disclosure of financial information may have led to increases in the level of pay to compensate executives for the disutility of stronger monitoring (Hermalin and Weisbach, 2009). These theories are consistent with the increasing fraction of CEOs being hired from outside the firm, the rise in managerial turnover, and the growth in the likelihood of forced 
departures (Hadlock and Lumer, 1997; Murphy, 1999; Huson, Parrino and Starks, 2001). Another explanation is that the IT revolution that began to take hold in the 1970s led to a form of skilled-biased technical change that altered the nature of the job of top managers (Garicano and Rossi-Hansberg, 2006). Finally, changes in the compensation of top executives might be related to more general factors that contributed to the rise in the relative incomes of all high-earners since the 1970s (Kaplan and Rauh, 2007), such as changes in social norms (Piketty and Saez, 2003; Levy and Temin, 2007). 


\section{Abbreviated Data Appendix}

This Data Appendix contains an abbreviated discussion of the sample selection, data collection, and other measurement issues. The Full Appendix with more comprehensive discussions of these topics is available on the Review of Financial Studies' and the authors' websites.

\section{Sample Selection}

\subsection{Selecting firms}

Our sample includes data on executives working in the largest 50 firms in 1940, 1960, and 1990. For 1960 and 1990, we measure firm size by the total value of sales and obtain company rankings from Compustat. ${ }^{58}$ Because Compustat's coverage is incomplete prior to 1978, we crosscheck the 1960 ranking with a list of the largest manufacturing firms published by Fortune magazine and add firms that are missing from Compustat. ${ }^{59}$ Since a rank ordering of firms by the value of total sales was not available for 1940, we rank firms in that year by their total market value using the Center for Research in Security Prices (CRSP) database.

Our information on executive compensation comes from historical proxy statements and 10-K reports, which were mainly obtained from the collection at Harvard Business School's Baker Library. To facilitate the data collection we limit our sample to firms with available proxy statements for at least 20 years. If a firm does not meet our selection criteria, we replace it with the next largest firm on the list until we have a total of 50 firms for each of the three years. Because the ranking of firms is fairly consistent over time, our final sample includes a total of

\footnotetext{
${ }^{58}$ Although we select firms based on rankings in three particular years, we intended to select companies that were large for a reasonable period of time. Consequently, we use the value sales to measure firm size when possible because it is less susceptible to transitory shocks than market value.

${ }^{59}$ See Kothari, Shanken, and Sloan (1995) for a more detailed description of survivorship bias in Compustat.
} 
101 firms. For each firm that meets our selection criteria, we collect annual data for all of the years from 1936 to 2005 for which proxy statements or 10-Ks are available. Although corporations were required to disclose the compensation of their top officers starting in 1934, we do not start our sample until 1936 because many firms did not comply with the regulation in the first few years.

For each firm, we collected data on the five highest-paid officers when available. However, many reports listed only the three highest-paid officers prior to 1978 so we limit our analysis to the top three officers. Our results are robust to including the fourth and fifth highestpaid executives.

\subsection{Collecting firm-level data}

We measure the market value of each firm as the number of shares outstanding multiplied by the end-of-fiscal year stock price, both of which are reported in CRSP. Other financial data are from Compustat, which provides accounting data for most companies from 1950 to the present. For years prior to 1950, we collect similar data from various editions of Moody's Industrial Manual, Moody's Transportation Manual, and Moody's Public Utility Manual. We also use these manuals to obtain information on the board of directors in 1936, 1950, 1970, and 1990.

Data on institutional investor ownership come from two sources. For the 1990s, we use the Dluglosz, Fahlenbrach, Gompers, and Metrick (DFGM) standardized data for blockholders that cover the years 1996-2001. When possible we use data from 1996, but in a few cases the earliest-available year was between 1997 and 2000. For the early part of our sample, we use a 1940 SEC study for the Temporary National Economic Committee on the concentration of 
economic power. This study provides information on the holdings of the 20 largest shareholders for the 200 largest non-financial corporations from the end of 1937 to early 1939.

\section{Measuring Executive Compensation}

Salary and current bonus payments: Salary plus any bonus both awarded and paid out in the same year, including cash and stock bonuses. Stock bonuses are valued using the stock price on the day the stock was given to the executive. Cash compensation is often reported as one lump sum prior to 1992, so we are unable to separate salary from bonus payments. ${ }^{60}$

Long-term incentive payments: Payments made to the executive for bonuses awarded in prior years. Many long-term incentive plans paid bonuses in equal installments during the four to five years after the award, although individual plans varied from two to ten years. We measure bonuses as the amount received during the year rather than the amount awarded (to be paid out in the future) because Compustat and some earlier proxy statements do not report information on bonuses awarded. Stock bonuses are valued using the stock price at the end of the fiscal year in which the stock is received. Since the realization of performance measures for contingent awards are usually not observable, contingent bonuses are only included when the amounts paid out are reported.

Stock option grants: We value options on the day they were granted using the Black-Scholes formula. In some cases — especially from the late 1960 s to the late 1980 s - firms reported only the total number of options awarded to each executive during the previous three or five years, rather than the number granted each year. Wherever possible, we combine these cumulative option awards with information on annual grants and exercises from previous proxy statements

\footnotetext{
${ }^{60}$ Current bonus payments sometimes include long-term bonus payments in the ExecuComp data.
} 
to estimate the amounts granted for each executive in an individual year. Otherwise, we impute missing grants and exercises for a given year assuming that one-fifth of the five-year totals were granted in each of the past five years, or one-third of the three-year totals in each of the past three years. We assume that the exercise price of these options was equal to the end-of-fiscal-year stock price.

Stock option exercises: We value gains from exercising options as the difference between the exercise price and the average stock price on the day the option was exercised. Proxy statements issued during the 1980s and 1990s generally report the total gains from exercising options, but not the number. In these cases, we assume the executive exercised the oldest options first in order to back out the number exercised. We impute the number exercised from three- and fiveyear totals during the 1970 s and 1980s using a procedure similar to the one used for option grants.

Stock option holdings: We calculate the number of options held by an executive as the number held in the previous year plus the number granted, less the number exercised and the number that expired during the year. To value holdings using the Black-Scholes formula, we gather information on the exercise price and duration of options based on information reported when the options were granted and exercised. When this information is missing, we assume that the exercise price is the closing price at the end of the fiscal year of the grant year and that options granted before 1964 or after 1974 have a duration of ten years, while options granted between 1964 and 1974 have a duration of five years. ${ }^{61}$

\footnotetext{
${ }^{61}$ Results are similar if we use a seven-year duration to account for early option exercises (Hall and Liebman, 1998).
} 
Equity holdings: Equity holdings are valued with the stock price at the end of the fiscal year. We include shares that are held by family members and associates. Equity holdings have been reported in proxy statements since 1942. We estimate stock holdings for the 1935-1941 period from bi-monthly reports of the SEC, Official Summary of Security Transactions and Holdings. The use of transactions data introduces noise in our measure of stock holdings for this period, but we do not find evidence of a large bias (see Full Appendix Section 2.3).

\section{Measuring other Firm-Level Variables}

Blockholders: An individual, institution, or corporation that owns more than 5\% of the firm's common stock. We define outside blockholders as any blockholder who is not employed by the firm or a member of the board of directors. These blockholders are nearly all institutions or corporations; results are similar when we exclude the few blockholders who are individuals. Due to data limitations, we were unable to separate institutional from corporate blockholders.

Fraction of inside directors: Number of directors that are "insiders" relative to the total number of board members. Following Lehn, Patro, and Zaho (2003), we define insiders as directors who are also executives of the firm in the same year, as listed in the Moody's Manuals.

Growth opportunities: Ratio of market-to book value, which we calculate as the sum of total liabilities and market value of equity divided by assets.

Noisiness of the stock price: We calculate idiosyncratic stock-price volatility as the five-year standard deviation of the residuals from a regression of the firm's rate of return on the rate of return of the S\&P 500. The regression is estimated using monthly data and includes all available years for each firm. Results are similar if we use the standard deviation of the actual stock price instead of the standard deviation of these residuals. 
Leverage: Ratio of total liabilities to total assets. Results are similar if we use the sum of shortterm and long-term debt relative to total assets. 


\section{References}

Aggarwal, R. K., and A. A. Samwick. 1999. The Other Side of the Trade-Off: The Impact of Risk on Executive Compensation. Journal of Political Economy 107(1):65-105.

Anderson, R. C., R. T. Boylan, and D. M. Reeb. 2007. Paying the CEO: A Model of Managerial Integrity Premiums. Working Paper, Temple University.

Baker, G., and B. Hall. 2004. CEO Incentives and Firm Size, Journal of Labor Economics 22(2):767-98.

Baker, J. C., and W. L. Crum. 1935. Compensation of Corporation Executives: The 1928-1932 Record. Harvard Business Review 13(Spring):321-33.

Baker, J. C. 1938. Executive Salaries and Bonus Plans. New York: McGraw-Hill Book Company.

Bates, T., T. Jandik, and K. Lehn. 2000. Promotion Incentives and Executive Compensation in Family Firms. Working Paper, University of Pittsburgh.

Bebchuk, L. A., and J. M. Fried. 2003. Executive Compensation as an Agency Problem. Journal of Economic Perspectives 17(Summer).

Bebchuk, L. A., and J. M. Fried. 2004. Pay without Performance: The Unfulfilled Promise of Executive Compensation. Cambridge: Harvard University Press.

Bebchuk, L. A., and R.t J. Jackson. 2005. Executive Pensions. Journal of Corporation Law 30(4):823-55.

Benjamin, D. J. 2005. A Theory of Fairness in Labor Markets. Working Paper, Harvard University.

Bergstresser, D., and T. Philippon. 2006. CEO incentives and earnings management. Journal of Financial Economics 80(3):511-29. 
Bertrand, M., and S. Mullainathan. 2001. Are CEOs Rewarded for Luck? The Ones Without Principals Are. Quarterly Journal of Economics 116(3):901-32.

Bizjak, J. M., J. A. Brickley and J. L. Coles. 1993. Stock-based Incentive Compensation and Investment Behavior. Journal of Accounting and Economics 16:349-72.

Bizjak, J. M., M. L. Lemmon and L. Naveen. 2008. Does the Use of Peer Groups Contribute to Higher Pay and Less Efficient Compensation? Journal of Financial Economics 90(2):15268.

Blanchflower, D. G., A. Oswald, and P. Sanfey. 1996. Wages, profits and rent sharing. Quarterly Journal of Economics 111(1):227-51.

Boone, A. L., L. C. Field, J. M. Karpoff, and C. G. Raheja. 2007. The Determinants of Corporate Board Size and Composition: An Empirical Analysis. Journal of Financial Economics $85: 66-101$.

Boschen, J. F., and K. J. Smith. 1995. You Can Pay Me Now and You Can Pay Me Later: The Dynamic Response of Executive Compensation to Firm Performance. Journal of Business, 68(4):577-608.

Coles, J. L., N. D. Daniel, and L. Naveen. 2006. Managerial incentives and risk-taking. Journal of Financial Economics 79(2):431-68.

Coles, J. L., N. D. Daniel, and L. Naveen. 2008. Boards: Does One Size Fit All? Journal of Financial Economics 87:329-56.

Coles, J. L., M. L. Lemmon, and J. F. Meschke. 2006. Structural Models and Endogeneity in Corporate Finance: The Link Between Managerial Ownership and Corporate Performance. Working Paper, University of Minnesota. 
Coles, J. L., M. L. Lemmon, and Y. Wang. 2008. The Joint Determinants of Managerial Ownership, Board Independence, and Firm Performance. Working Paper, Second Singapore International Conference on Finance.

Core, J., and W. Guay. 1999. The Use of Equity Grants to Manage Optimal Equity Incentive Levels. Journal of Accounting and Economics 28:151-84.

Core, J., and W. Guay. 2002. Estimating the Value of Employee Stock Option Portfolios and Their Sensitivities to Price Volatility. Journal of Accounting Research 40:613-30.

Core, J., R. W. Holthausen, and D. F. Larcker. 1999. Corporate Governance, Chief Executive Officer Compensation, and Firm Performance. Journal of Financial Economics 51:371-406.

Cuñat, V. and M. Guadalupe. 2006. Globalization and the Provision of Incentives Inside the Firm: The Effect of Foreign Competition. Working Paper, Columbia University Graduate School of Business.

Demsetz, H., and K. Lehn. 1985. The Structure of Corporate Ownership: Causes and Consequences. Journal of Political Economy 93:1155-77.

Edmans, A., X. Gabaix, and A. Landier. 2007. A Calibratable Model of Optimal CEO Incentives in Market Equilibrium. Working Paper 13372, National Bureau of Economic Research.

Frydman, C. 2005. Rising through the Ranks: The Evolution of the Market for Corporate Executives, 1936-2003. Working Paper, M.I.T. Sloan School of Management.

Frydman, C., and R. S. Molloy. 2009. Does Tax Policy Affect Executive Compensation? Evidence from Postwar Tax Reforms. Working Paper 2009-30, Federal Reserve Board of Governors.

Gabaix, X., and A. Landier. 2008. Why Has CEO Pay Increased So Much? Quarterly Journal of Economics 123(1):49-100. 
Garicano, L., and E. Rossi-Hansberg. 2006. Organization and Inequality in a Knowledge Economy. Quarterly Journal of Economics 121(4):1282-435.

Garen, J. E. 1994. Executive Compensation and Principal-Agent Theory. Journal of Political Economy 102:1175-99.

Gillan, S. L., and L. T. Starks. 2007. The Evolution of Shareholder Activism in the United States. Journal of Applied Corporate Finance 19:55-73.

Goldin, C., and R. A. Margo. 1992. The Great Compression: The Wage Structure in the United States at Mid-Century. Quarterly Journal of Economics 107:1-34.

Hadlock, C. J., and G. B. Lumer. 1997. Compensation, Turnover, and Top Management Incentives: Historical Evidence. Journal of Business 70(2):153-87.

Hall, B. J., and J. B. Liebman. 1998. Are CEOs Really Paid like Bureaucrats? Quarterly Journal of Economics 113(August):653-91.

Hall, B. J., and K. J. Murphy. 2002. Stock options for Undiversified Executives. Journal of Accounting and Economics 33:3-42.

Hall, B. J., and K. J. Murphy. 2003. The Trouble with Stock Options. Journal of Economic Perspectives 17(Summer):49-70.

Harris, M., and A. Raviv. 2008. A Theory of Board Control and Size. Review of Financial Studies 21(4): 1797-832.

Hartzell, J. C., and L. T. Starks. 2003. Institutional Investors and Executive Compensation. Journal of Finance 58(6):2351-74.

Haubrich, J. G. 1994. Risk Aversion, Performance Pay, and the Principal-Agent Problem. Journal of Political Economy 102:258-76.

Hermalin, B. E. 2005. Trends in Corporate Governance. Journal of Finance 60:2351-84. 
Hermalin, B. E., and M. S. Weisbach. 1998. Endogenously Chosen Boards of Directors and Their Monitoring of the CEO. American Economic Review 88:96-118.

Hermalin, B. E., and M. S. Weisbach. 2003. Boards of Directors as an Endogenously Determined Institution: A Survey of the Economic Literature. FRBNY Economic Policy Review 9(1):726.

Hermalin, B. E., and M. S. Weisbach. 2009. Information Disclosure and Corporate Governance. Working Paper, Ohio State University.

Himmelberg, C. P., and R. G. Hubbard. 2000. Incentive Pay and the Market for CEOs: An Analysis of Pay-for-Performance Sensitivity. Working Paper, Columbia University.

Holderness, C. G., R. S. Kroszner and D. P. Sheehan. 1999. Were the Good Old Days That Good? Changes in Managerial Stock Ownership Since the Great Depression. Journal of Finance 54(2):435-69.

Holmstrom, B. 1979. Moral Hazard and Observability. The Bell Journal of Economics 10(1):7491.

Holmstrom, B. 2005. Pay without Performance and the Managerial Power Hypothesis: A Comment. Journal of Corporation Law 30:675-702.

Holmstrom, B., and S. N. Kaplan. 2001. Corporate Governance and Merger Activity in the U.S.: Making Sense of the 1980s and 1990s. Working Paper 8220, National Bureau of Economic Research.

Huson, M. R., R. Parrino, and L. T. Starks. 2001. Internal Monitoring Mechanisms and CEO Turnover: A Long-Term Perspective. Journal of Finance 56(6):2265-97.

Inderst, R., and H. M. Mueller. 2006. CEO Compensation and Private Information: An Optimal Contracting Perspective. Working Paper, New York University. 
Jensen, M. C. 1993. The Modern Industrial Revolution, Exit, and the Failure of Internal Control Systems. Journal of Finance 48:831-80.

Jensen, M., and K. J. Murphy. 1990. Performance Pay and Top-Management Incentives. Journal of Political Economy 98(2):225-64.

Jensen, M. C., K. J. Murphy, and E. Wruck. 2004. Remuneration: Where We've Been, How We Got to Here, What are the Problems, and How to Fix Them. Working Paper, European Corporate Governance Institute.

Joskow, P. L., and N. L. Rose. 1994. CEO Pay and Firm Performance: Dynamics, Asymmetries, and Alternative Performance Measures. Working Paper 4976, National Bureau of Economic Research.

Kaplan, S. N., and J. Rauh. 2007. Wall Street and Main Street: What Contributed to the Rise in the Highest Incomes? Working Paper 615, Center for Research in Security Prices.

Kostiuk, P. 1990. Firm Size and Executive Compensation. Journal of Human Resources 25:90105.

Kothari, S.P., J. Shanken, and R. G. Sloan. 1995. Another Look at the Cross-section of Expected Stock Returns. Journal of Finance 50:185-224.

Kuhnen, C. M., and J. H. Zwiebel. 2007. Executive Pay, Hidden Compensation and Managerial Entrenchment. Working Paper.

Khurana, R. 2002. Searching for a Corporate Savior. The Irrational Quest for Charismatic CEOs. New Jersey: Princeton University Press.

Lehn, K., S., Patro, and M. Zhao. 2008. Determinants of the Size and Structure of Corporate Boards: 1935-2000. Working Paper, Kellogg School of Management. 
Levy, F. S., and P. Temin. 2007. Inequality and Institutions in $20^{\text {th }}$ Century America. Working Paper 07-17, M.I.T. Department of Economics.

Lewellen, W. G. 1968. Executive Compensation in Large Industrial Corporations. New York: National Bureau of Economic Research.

Link, J. S., J. M. Netter, and T. Yang. 2008. The Determinants of Board Structure. Journal of Financial Economics 87:308-28.

Lucas Jr., R. E. 1978. On the Size Distribution of Business Firms. The Bell Journal of Economics 9(2):508-23.

Mace, M. L. 1971. Directors, Myth and Reality. Boston, MA: Harvard Business School Press.

Masson, R. 1971. Executive Motivations, Earnings, and Consequent Equity Performance. Journal of Political Economy 79:1278-92.

McGahran, K. T. 1988. SEC Disclosure Regulation and Management Perquisites. The Accounting Review 63(1):23-42.

Mehran, H. 1995. Executive Compensation, Ownership, and Firm Performance. Journal of Financial Economics 38:163-84.

Murphy, K. J. 1985. Corporate Performance and Managerial Remuneration: An Empirical Analysis. Journal of Accounting and Economics 7:11-42.

Murphy, K. J. 1999. Executive Compensation. In Orley Ashenfelter and David Card (eds.), Handbook of Labor Economics 3B. Amsterdam, New York: North Holland.

Murphy, K. J., and J. Zábojník. 2004. CEO Pay and Turnover: A Market Based Explanation for Recent Trends. American Economic Review Papers and Proceedings 94:192-96.

Patton, A. 1961. Men Money and Motivation. New York, NY: McGraw-Hill Book Company. Patton, A. 1994. The Making of Multimillion-Dollar Executives. Business Horizons May-June. 
Pesaran, M. H. 2007. A Simple Panel Unit Root Test in the Presence of Cross-Section Dependence. Journal of Applied Econometrics 22:265-312.

Piketty, T., and E. Saez. 2003. Income Inequality in the United States: 1913-1998. Quarterly Journal of Economics 118:1-39.

Rajan, R. G., and J. Wulf. 2006. Are Perks Purely Managerial Excess? Journal of Financial Economics 79:1-33.

Roberts, D. 1956. A General Theory of Executive Compensation Based on Statistically Tested Propositions. Quarterly Journal of Economics 70:270-94.

Roberts, D. 1959. Executive Compensation. Glencoe, IL: The Free Press.

Rosen, S. 1981. The Economics of Superstars. American Economic Review 71:845-58.

Rosen, S. 1982. Authority, Control and the Distribution of Earnings. Bell Journal of Economics $13: 311-23$.

Rosen, S. 1992. Contracts and the Market for Executives. In Lars Werin and Hans Wijkander (eds.), Contract Economics. Cambridge, MA: Blackwell Publishers.

Schaeffer, S. 1998. The Dependence of Pay-Performance Sensitivity on the Size of the Firm. Review of Economics and Statistics 80:436-43.

Smith, C. W. Jr., and J. L. Zimmerman. 1976. Valuing Employee Stock Option Plans Using Option Pricing Models. Journal of Accounting Research 14:357-64.

Smith, C. W. Jr., and R. L. Watts. 1992. The Investment Opportunity Set and Corporate Financing, Dividend, and Compensation Policies. Journal of Financial Economics 32:26392.

Sundaram, R. K., and D. Yermack. 2005. Pay Me Later: Inside Debt and its Role in Managerial Compensation. NYU Law and Economics Research Paper 05-08. 
Taussig, F. W., and W. S. Barker. 1925. American Corporations and Their Executives: A Statistical Inquiry. Quarterly Journal of Economics 40:1-51.

Tervio, M. 2008. The Difference That CEOs Make: An Assignment Model Approach. American Economic Review 98(3): 642-68.

Wattel, H. L. 1978. Chief Executive Officer Compensation. New York: Hofstra University.

Yermack, D. 1995. Do Corporations Award CEO Stock Options Effectively? Journal of Financial Economics 39:237-69.

Yermack, D. 2006. Flights of Fancy: Corporate Jets, CEO Perquisites, and Inferior Shareholder Returns. Journal of Financial Economics 80:211-42. 


\section{Table 1}

Sample summary statistics

\begin{tabular}{lc}
\hline & $1936-2005$ \\
\hline Total \# of person-year observations & 15883 \\
Total \# of executives & 2862 \\
Average \# of firms in each year & 76 \\
Average \# of years each executive is observed & 5.6 \\
Median \# of years each executive is observed & 4 \\
Fraction of obs. in firms with market value & 39.0 \\
Ranked 1-50 & 19.6 \\
Ranked 50-100 & 19.1 \\
Ranked 100-200 & 16.7 \\
Ranked 200-500 & 5.4 \\
Ranked 500+ & \\
& \\
&
\end{tabular}




\section{Table 2}

Distribution of job titles

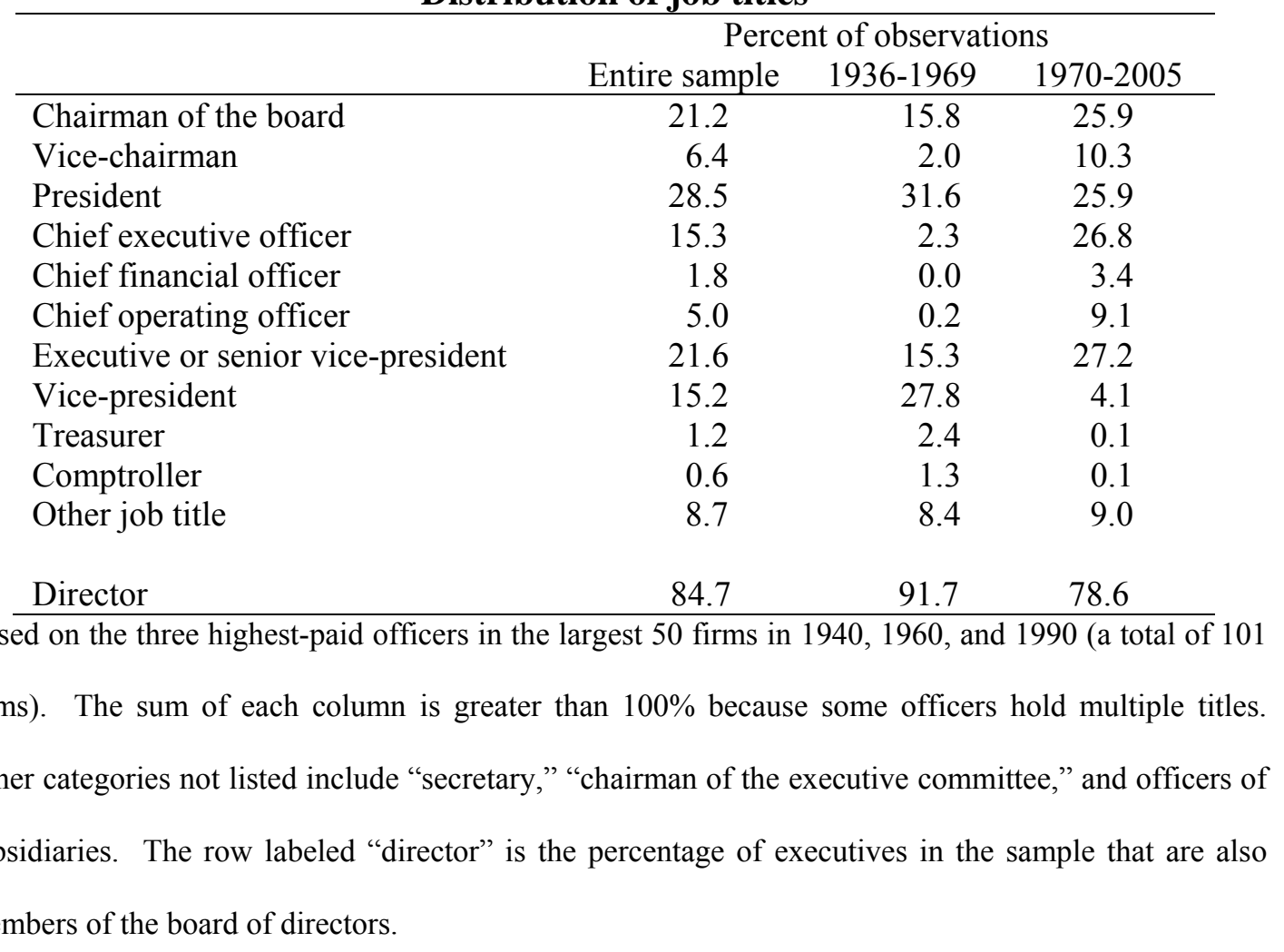


Table 3

Level and structure of total compensation by percentile and CEO status

\begin{tabular}{|c|c|c|c|c|c|c|c|c|c|}
\hline & $\begin{array}{l}1936- \\
1939\end{array}$ & $\begin{array}{l}1940- \\
1945 \\
\end{array}$ & $\begin{array}{l}1946- \\
1949\end{array}$ & $\begin{array}{l}1950- \\
1959\end{array}$ & $\begin{array}{l}1960- \\
1969 \\
\end{array}$ & $\begin{array}{l}1970- \\
1979\end{array}$ & $\begin{array}{l}1980- \\
1989\end{array}$ & $\begin{array}{l}1990- \\
1999\end{array}$ & $\begin{array}{l}2000- \\
2005\end{array}$ \\
\hline & \multicolumn{9}{|c|}{ Panel A: Level of Total Compensation (Millions of Year 2000 Dollars) } \\
\hline \multicolumn{10}{|l|}{ Three Highest-Paid Officers } \\
\hline $10^{\text {th }}$ percentile & 0.36 & 0.4 & 0.36 & 0.39 & 0.45 & 0.47 & 0.57 & 0.91 & 1.31 \\
\hline $25^{\text {th }}$ percentile & 0.53 & 0.59 & 0.53 & 0.55 & 0.60 & 0.64 & 0.85 & 1.35 & 2.19 \\
\hline $50^{\text {th }}$ percentile & 0.85 & 0.80 & 0.72 & 0.77 & 0.83 & 0.93 & 1.33 & 2.36 & 4.08 \\
\hline $75^{\text {th }}$ percentile & 1.24 & 1.15 & 1.01 & 1.09 & 1.18 & 1.31 & 2.05 & 4.43 & 9.42 \\
\hline $90^{\text {th }}$ percentile & 1.80 & 1.59 & 1.53 & 1.63 & 1.66 & 1.84 & 3.18 & 8.29 & 16.9 \\
\hline average & 0.97 & 0.95 & 0.85 & 0.94 & 0.99 & 1.09 & 1.74 & 4.35 & 7.63 \\
\hline Median CEO & 1.11 & 1.07 & 0.90 & 0.97 & 0.99 & 1.17 & 1.81 & 4.09 & 9.20 \\
\hline Median Other Top Officers & 0.74 & 0.70 & 0.65 & 0.67 & 0.74 & 0.82 & 1.12 & 1.89 & 3.02 \\
\hline $\begin{array}{l}\text { Within-Firm Ratio of CEO to } \\
\text { Other Top Officers }\end{array}$ & 1.50 & 1.48 & 1.38 & 1.43 & 1.29 & 1.42 & 1.58 & 2.00 & 2.58 \\
\hline \multicolumn{10}{|c|}{ Panel B: Structure of Compensation } \\
\hline \multicolumn{10}{|c|}{ Average Long-Term Pay / Total Compensation } \\
\hline CEOs & 0.00 & 0.01 & 0.01 & 0.03 & 0.06 & 0.05 & 0.07 & 0.15 & 0.23 \\
\hline Other Top Officers & 0.00 & 0.01 & 0.01 & 0.03 & 0.05 & 0.05 & 0.07 & 0.15 & 0.22 \\
\hline \multicolumn{10}{|c|}{ Average Stock Option Grants / Total Compensation } \\
\hline CEOs & 0.00 & 0.00 & 0.00 & 0.04 & 0.07 & 0.11 & 0.19 & 0.32 & 0.37 \\
\hline Other Top Officers & 0.00 & 0.00 & 0.00 & 0.03 & 0.05 & 0.10 & 0.17 & 0.27 & 0.31 \\
\hline
\end{tabular}

Total compensation is the sum of salaries, bonuses, long-term bonus payments, and the Black-Scholes value of stock option grants. Long-

term pay is payouts from long-term bonus awards made in prior years, including restricted stock. Based on the three highest-paid officers in the largest 50 firms in 1940, 1960, and 1990. In firms where the title "CEO" is not used, the CEO is identified as the president of the company. Other top officers include any executive among the three highest-paid who is not the CEO. The within-firm ratio is the median across firms of the ratio of the CEO's total compensation to the average compensation of the two other highest-paid officers in the firm. 
Table 4

The correlation between compensation and firm size

\begin{tabular}{|c|c|c|c|c|c|}
\hline & \multicolumn{3}{|c|}{ Firm Size $=$ Ln(Market Value $)$} & \multicolumn{2}{|c|}{ Firm Size $=$ Ln(Sales) } \\
\hline & $\begin{array}{l}1936-1975 \\
\text { (1) }\end{array}$ & $\begin{array}{c}1946-1975 \\
(2)\end{array}$ & $\begin{array}{l}1976-2005 \\
\text { (3) }\end{array}$ & $\begin{array}{c}1946-1975 \\
\text { (4) }\end{array}$ & $\begin{array}{l}1976-2005 \\
(5)\end{array}$ \\
\hline Panel 1: DV = Ln(Comp $\left.{ }_{\text {ift }}\right)$ & & & & & \\
\hline $\begin{array}{l}\text { Average Size in Year } t \\
\text { [fraction variance explained] }\end{array}$ & $\begin{array}{l}.088^{* *} \\
(.026) \\
{[.010]}\end{array}$ & $\begin{array}{l}.137 * * \\
(.025) \\
{[.020]}\end{array}$ & $\begin{array}{l}.935^{* *} \\
(.035) \\
{[.332]}\end{array}$ & $\begin{array}{l}.157^{* *} \\
(.032) \\
{[.017]}\end{array}$ & $\begin{array}{l}2.65^{* *} \\
(0.11) \\
{[.259]}\end{array}$ \\
\hline $\begin{array}{l}\text { Average Firm Size } \\
\text { [fraction variance explained] }\end{array}$ & $\begin{array}{l}.208^{* *} \\
(.033) \\
{[.145]}\end{array}$ & $\begin{array}{l}.212^{* *} \\
(.032) \\
{[.164]}\end{array}$ & $\begin{array}{l}.292 * * \\
(.032) \\
{[.135]}\end{array}$ & $\begin{array}{l}.305^{* *} \\
(.037) \\
{[.220]}\end{array}$ & $\begin{array}{l}.358^{* *} \\
(.041) \\
{[.113]}\end{array}$ \\
\hline $\begin{array}{l}\text { Size - Firm Avg. - Year Avg. } \\
\text { [fraction variance explained] }\end{array}$ & $\begin{array}{l}.182 * * \\
(.038) \\
{[.039]}\end{array}$ & $\begin{array}{l}.199 * * \\
(.041) \\
{[.036]}\end{array}$ & $\begin{array}{l}.264 * * \\
(.032) \\
{[.043]}\end{array}$ & $\begin{array}{l}.240 * * \\
(.052) \\
{[.041]}\end{array}$ & $\begin{array}{l}.346^{* *} \\
(.048) \\
{[.032]}\end{array}$ \\
\hline $\begin{array}{l}\text { Panel 2: With Firm Fixed Effects } \\
\text { Average Size in Year } t\end{array}$ & & $\begin{array}{l}.135^{* *} \\
(.024)\end{array}$ & $\begin{array}{l}.969 * * \\
(.037)\end{array}$ & $\begin{array}{l}.149 * * \\
(.031)\end{array}$ & $\begin{array}{l}2.63^{* *} \\
(0.11)\end{array}$ \\
\hline Size - Year Avg. & & $\begin{array}{l}.218^{* *} \\
(.040)\end{array}$ & $\begin{array}{l}.313 * * \\
(.028)\end{array}$ & $\begin{array}{l}.277^{* *} \\
(.046)\end{array}$ & $\begin{array}{l}.389 * * \\
(.046)\end{array}$ \\
\hline $\begin{array}{l}\text { Panel 3: Including Lagged Size an } \\
\text { Firm FE }\end{array}$ & & & & & \\
\hline Average Size in Year $t$ & & $\begin{array}{l}-.019 \\
(.037)\end{array}$ & $\begin{array}{l}.622 * * \\
(.086)\end{array}$ & $\begin{array}{l}.240^{* *} \\
(.074)\end{array}$ & $\begin{array}{l}2.31^{* *} \\
(0.23)\end{array}$ \\
\hline Average Size in Year $t-1$ & & $\begin{array}{l}.152^{* *} \\
(.041)\end{array}$ & $\begin{array}{l}.378^{* *} \\
(.083)\end{array}$ & $\begin{array}{l}-.088 \\
(.063)\end{array}$ & $\begin{array}{l}.362^{*} \\
(.210)\end{array}$ \\
\hline (Size - Year Avg.) in Year $t$ & & $\begin{array}{l}.183 * * \\
(.040)\end{array}$ & $\begin{array}{l}.369 * * \\
(.038)\end{array}$ & $\begin{array}{l}.203^{* *} \\
(.045)\end{array}$ & $\begin{array}{l}.401 * * \\
(.067)\end{array}$ \\
\hline (Size - Year Avg.) in Year $t-1$ & & $\begin{array}{l}.020 \\
(.041)\end{array}$ & $\begin{array}{l}-.064 * * \\
(.029)\end{array}$ & $\begin{array}{l}.084 * * \\
(.030)\end{array}$ & $\begin{array}{l}-.040 \\
(.043)\end{array}$ \\
\hline $\begin{array}{l}\text { Panel 4: Including Quadratic Tim } \\
\text { Trend and Firm FE }\end{array}$ & & & & & \\
\hline Average Size in Year $t$ & & $\begin{array}{l}.035 \\
(.032)\end{array}$ & $\begin{array}{l}.750^{* *} \\
(.082)\end{array}$ & $\begin{array}{l}.143^{*} \\
(.079)\end{array}$ & $\begin{array}{l}-.312^{*} \\
(.171)\end{array}$ \\
\hline Size - Year Avg. & & $\begin{array}{l}.217^{* *} \\
(.038)\end{array}$ & $\begin{array}{l}.309^{* *} \\
(.028)\end{array}$ & $\begin{array}{l}.272^{* *} \\
(.046)\end{array}$ & $\begin{array}{l}.391 * * \\
(.042)\end{array}$ \\
\hline $\begin{array}{c}\text { Panel 5: } \mathbf{D V}=\Delta \mathbf{L n}\left(\text { Comp }_{i f t}\right) \\
\Delta \text { Average Size in Year } t\end{array}$ & & $\begin{array}{l}.012 \\
(.031)\end{array}$ & $\begin{array}{l}.210^{* *} \\
(.080)\end{array}$ & $\begin{array}{l}.087^{*} \\
(.049)\end{array}$ & $\begin{array}{l}.172 \\
(.174)\end{array}$ \\
\hline$\Delta$ Size $-\Delta$ Year Avg. & & $\begin{array}{l}.092 * * \\
(.032)\end{array}$ & $\begin{array}{l}.277 * * \\
(.035)\end{array}$ & $\begin{array}{l}.077 * * \\
(.024)\end{array}$ & $\begin{array}{l}.145 \\
(.116)\end{array}$ \\
\hline
\end{tabular}

The dependent variable in Panels 1 to 4 is $\ln$ (total compensation) of each executive and the dependent variable in Panel 5 is the annual change in $\ln ($ compensation) of each executive. Total compensation is the sum of salaries, bonuses, long-term bonus payments, and the Black-Scholes value of stock option grants, measured in year 2000 dollars and based on the three highest-paid officers in the largest 50 firms in 1940, 1960, and 1990 (a total of 101 firms). Size is measured by the logarithm of the firm's market value in columns (1) to (3) and by the logarithm of the firm's total sales in columns (4) to (5), both measured in year 2000 dollars. Standard errors are shown in parentheses and are clustered by firm. Values in brackets show the fraction of the total variance explained by each independent variable based on an ANOVA decomposition for each sample period. * denotes significance at the $10 \%$ level and ** denotes significance at the $5 \%$ level. 
Table 5

Managerial stock holdings relative to shares outstanding (percentage points)

\begin{tabular}{cccc|cc}
\hline & $\begin{array}{c}25^{\text {th }} \\
\text { percentile }\end{array}$ & $\begin{array}{c}50^{\text {th }} \\
\text { percentile }\end{array}$ & $\begin{array}{c}75^{\text {th }} \\
\text { percentile }\end{array}$ & $\begin{array}{c}\text { CEOs } \\
\text { (median) }\end{array}$ & $\begin{array}{c}\text { Other Highest- } \\
\text { Paid Officers } \\
\text { (median) }\end{array}$ \\
\hline $1936-1940$ & .019 & .111 & .402 & .130 & .088 \\
$1941-1949$ & .010 & .038 & .159 & .048 & .031 \\
$1950-1959$ & .011 & .035 & .109 & .043 & .031 \\
$1960-1969$ & .012 & .037 & .103 & .047 & .034 \\
$1970-1979$ & .008 & .023 & .064 & .039 & .019 \\
$1980-1989$ & .008 & .019 & .054 & .029 & .015 \\
$1990-1999$ & .011 & .030 & .084 & .069 & .021 \\
$2000-2005$ & .010 & .028 & .074 & .072 & .018 \\
\hline
\end{tabular}

The proportion of managerial stock holdings relative to shares outstanding at the $25^{\text {th }}, 50^{\text {th }}$, and $75^{\text {th }}$ percentiles are based on the three-highest paid executives in the 50 largest firms in 1940, 1960, and 1990 (a total of 101 firms). In firms where the title "CEO" is not used in the proxy statement, the CEO is identified as the president of the company. Other top officers include any executive among the three highest-paid who is not the CEO. 


\section{Table 6}

Ex-ante changes in the value of executives' stock and stock option holdings

\begin{tabular}{|c|c|c|c|c|c|c|}
\hline \multicolumn{7}{|c|}{ (year 2000 dollars) } \\
\hline & \multicolumn{2}{|c|}{ Option Holdings } & \multicolumn{2}{|c|}{ Stock Holdings } & \multicolumn{2}{|c|}{ Stock + Option Holdings } \\
\hline & $\begin{array}{c}\text { For } \$ 1000 \\
\text { change in } \\
\text { firm market } \\
\text { value } \\
\text { (Jensen- } \\
\text { Murphy) } \\
\text { (1) }\end{array}$ & $\begin{array}{l}\text { For a } 1 \% \\
\text { increase in } \\
\text { firm's rate of } \\
\text { return } \\
\text { (Equity at } \\
\text { Stake) } \\
(2)\end{array}$ & $\begin{array}{c}\text { For } \$ 1000 \\
\text { change in } \\
\text { firm market } \\
\text { value } \\
\text { (Jensen- } \\
\text { Murphy) } \\
(3)\end{array}$ & $\begin{array}{l}\text { For a } 1 \% \\
\text { increase in } \\
\text { firm's rate of } \\
\text { return } \\
\text { (Equity at } \\
\text { Stake) } \\
(4)\end{array}$ & $\begin{array}{c}\text { For } \$ 1000 \\
\text { change in firm } \\
\text { market value } \\
\text { (Jensen- } \\
\text { Murphy) } \\
(5) \\
\end{array}$ & $\begin{array}{l}\text { For a } 1 \% \\
\text { increase in } \\
\text { firm's rate of } \\
\text { return } \\
\text { (Equity at } \\
\text { Stake) } \\
(6)\end{array}$ \\
\hline 1936-1940 & 0 & 0 & 1.35 & 18,401 & 1.35 & 18,670 \\
\hline $1941-1949$ & 0 & 0 & 0.39 & 6,530 & 0.399 & 6,814 \\
\hline $1950-1959$ & 0 & 0 & 0.31 & 9,392 & 0.452 & 13,975 \\
\hline 1960-1969 & 0.11 & 7,913 & 0.35 & 20,531 & 0.675 & 38,978 \\
\hline $1970-1979$ & 0.12 & 6,303 & 0.22 & 11,766 & 0.470 & 21,743 \\
\hline 1980-1989 & 0.24 & 13,056 & 0.17 & 12,735 & 0.551 & 34,679 \\
\hline 1990-1999 & 0.41 & 57,975 & 0.29 & 36,273 & 0.946 & 120,342 \\
\hline $2000-2005$ & 0.65 & 127,195 & 0.27 & 49,729 & 1.08 & 227,881 \\
\hline
\end{tabular}

Based on the three-highest paid executives in the 50 largest firms in 1940, 1960, and 1990. Each column shows the median across all executives in each decade. Ex-ante revaluations of stock options are computed using the "delta" for the portfolio held by each executive (Core and Guay, 2002). Columns (5) and (6) report the median across executives of the sum of the ex-ante revaluations of stock and stock option holdings. 
Table 7

Correlation of pay-to-performance with firm characteristics

\begin{tabular}{|c|c|c|c|c|}
\hline & $1936-39$ & $1950-59$ & $1970-79$ & $1990-99$ \\
\hline Fraction of inside directors & $\begin{array}{l}3.041 \\
(0.990)^{*}\end{array}$ & $\begin{array}{l}1.002 \\
(0.677)\end{array}$ & $\begin{array}{l}0.038 \\
(0.934)\end{array}$ & $\begin{array}{l}1.138 \\
(1.042)\end{array}$ \\
\hline $\operatorname{Ln}(\#$ directors $)$ & $\begin{array}{l}1.584 \\
(0.572)^{*}\end{array}$ & $\begin{array}{l}0.082 \\
(0.366)\end{array}$ & $\begin{array}{l}-0.424 \\
(0.483)\end{array}$ & $\begin{array}{l}-0.862 \\
(0.518)\end{array}$ \\
\hline Ln(average market value in past 3 years) & $\begin{array}{l}0.323 \\
(0.210)\end{array}$ & $\begin{array}{l}0.319 \\
(0.125)^{*}\end{array}$ & $\begin{array}{l}0.405 \\
(0.102) *\end{array}$ & $\begin{array}{l}0.631 \\
(0.106)^{*}\end{array}$ \\
\hline Leverage $_{t-1}$ & $\begin{array}{l}-0.655 \\
(1.087)\end{array}$ & $\begin{array}{l}3.453 \\
(0.754)^{*}\end{array}$ & $\begin{array}{l}2.067 \\
(1.201)\end{array}$ & $\begin{array}{l}0.499 \\
(0.482)\end{array}$ \\
\hline Growth opportunities $_{\mathrm{t}-1}$ & $\begin{array}{l}0.464 \\
(0.155)^{*}\end{array}$ & $\begin{array}{l}0.711 \\
(0.308)^{*}\end{array}$ & $\begin{array}{l}0.613 \\
(0.199) *\end{array}$ & $\begin{array}{l}0.188 \\
(0.083)^{*}\end{array}$ \\
\hline Idiosyncratic stock-price volatility $_{\mathrm{t}-1}$ & $\begin{array}{l}0.087 \\
(0.498)\end{array}$ & $\begin{array}{l}-0.474 \\
(0.421)\end{array}$ & $\begin{array}{l}1.052 \\
(0.378)^{*}\end{array}$ & $\begin{array}{l}0.415 \\
(0.280)\end{array}$ \\
\hline Real rate of return ${ }_{t-1}$ & $\begin{array}{l}-0.169 \\
(0.072)^{*}\end{array}$ & $\begin{array}{l}0.088 \\
(0.201)\end{array}$ & $\begin{array}{l}0.053 \\
(0.116)\end{array}$ & $\begin{array}{l}0.127 \\
(0.132)\end{array}$ \\
\hline \multicolumn{5}{|c|}{ Industry indicators (relative to other manufacturing) } \\
\hline Railroad & $\begin{array}{l}-2.332 \\
(1.164)^{*}\end{array}$ & $\begin{array}{l}-0.336 \\
(0.369)\end{array}$ & $\begin{array}{l}-1.152 \\
(0.321)^{*}\end{array}$ & $\begin{array}{l}0.904 \\
(0.521)\end{array}$ \\
\hline Communications & -- & $\begin{array}{l}-1.929 \\
(0.399) *\end{array}$ & $\begin{array}{l}-2.047 \\
(0.403)^{*}\end{array}$ & $\begin{array}{l}-1.769 \\
(0.419) *\end{array}$ \\
\hline Utilities & $\begin{array}{l}-1.040 \\
(0.573)\end{array}$ & $\begin{array}{l}-2.187 \\
(0.439) *\end{array}$ & $\begin{array}{l}-1.653 \\
(0.543) *\end{array}$ & $\begin{array}{l}-2.055 \\
(0.521)^{*}\end{array}$ \\
\hline Trade & $\begin{array}{l}0.547 \\
(0.453)\end{array}$ & $\begin{array}{l}-0.327 \\
(0.422)\end{array}$ & $\begin{array}{l}0.264 \\
(0.263)\end{array}$ & $\begin{array}{l}-0.057 \\
(0.238)\end{array}$ \\
\hline Finance, insurance and real estate & $\begin{array}{l}0.167 \\
(0.750)\end{array}$ & $\begin{array}{l}-1.025 \\
(0.501)^{*}\end{array}$ & $\begin{array}{l}-0.438 \\
(0.551)\end{array}$ & $\begin{array}{l}0.322 \\
(0.348)\end{array}$ \\
\hline Chemical manufacturing & $\begin{array}{l}0.204 \\
(0.613)\end{array}$ & $\begin{array}{l}0.201 \\
(0.405)\end{array}$ & $\begin{array}{l}0.121 \\
(0.359)\end{array}$ & $\begin{array}{l}0.335 \\
(0.178)\end{array}$ \\
\hline Industrial equipment & $\begin{array}{l}0.929 \\
(0.702)\end{array}$ & $\begin{array}{l}-0.377 \\
(0.551)\end{array}$ & $\begin{array}{l}0.334 \\
(0.393)\end{array}$ & $\begin{array}{l}-0.296 \\
(0.284)\end{array}$ \\
\hline Electronic equipment & $\begin{array}{l}-2.354 \\
(0.608)^{*}\end{array}$ & $\begin{array}{l}-0.401 \\
(0.280)\end{array}$ & $\begin{array}{l}-0.091 \\
(0.434)\end{array}$ & $\begin{array}{l}0.409 \\
(0.472)\end{array}$ \\
\hline Number of observations & 404 & 1432 & 2089 & 1814 \\
\hline Adjusted R-squared & 0.37 & 0.43 & 0.36 & 0.52 \\
\hline
\end{tabular}

Pay-to-performance is defined as $\ln$ (equity-at-stake), but results are similar when using $\ln ($ Jensen-Murphy statistic). Fraction of inside directors is the number of directors that are managers of the firm relative to the total number of directors. Leverage is the ratio of total liabilities to assets. We proxy for growth opportunities with the market-to-book ratio, calculated as sum of total liabilities and market value of equity divided by assets. Idiosyncratic stock-price volatility is the five-year standard deviation of the residuals 
from a regression of the firm's rate of return on the rate of return of the S\&P 500. The omitted industry indicator corresponds to all other manufacturing firms in our sample. Regressions also include year and job title indicators. Standard errors are clustered by firm. * denotes statistical significance at the $5 \%$ level. 


\section{Table 8}

The strength of managerial incentives: change in wealth due to raising the firm's rate of return from the $50^{\text {th }}$ to the $70^{\text {th }}$ percentile

\section{Median Across Executives}

\begin{tabular}{|c|c|c|c|}
\hline & \multirow[t]{2}{*}{$\$$ change in wealth } & $\begin{array}{c}\text { Percentage change in wealth }= \\
\text { (1) }\end{array}$ & $\begin{array}{c}\text { Elasticity }= \\
(2)\end{array}$ \\
\hline & & total comp. $+\Delta$ wealth at rate of return ${ }^{50 \text { th }}$ & rate of return ${ }^{70 \text { th }}-$ rate of return $^{50 \text { th }}$ \\
\hline & (1) & (2) & (3) \\
\hline $1936-1940$ & 265,270 & 28.6 & 2.00 \\
\hline $1941-1949$ & 96,947 & 9.2 & 0.64 \\
\hline $1950-1959$ & 199,046 & 22.9 & 1.60 \\
\hline $1960-1969$ & 556,247 & 50.7 & 3.54 \\
\hline $1970-1979$ & 312,559 & 29.0 & 2.03 \\
\hline $1980-1989$ & 496,266 & 27.6 & 1.92 \\
\hline $1990-1999$ & $1,720,953$ & 52.3 & 3.66 \\
\hline $2000-2005$ & $3,212,822$ & 59.0 & 4.12 \\
\hline
\end{tabular}

Note. Based on the three-highest paid executives in the 50 largest firms in 1940, 1960, and 1990 (a total of 101). The dollar change in wealth is defined as the ex-ante revaluation of stock and option holdings assuming a rate of return at the $70^{\text {th }}$ percentile $(22.7 \%)$ minus the revaluation evaluated at the $50^{\text {th }}$ percentile rate of return (8.4\%). Column (1) shows the median of this value across executives in each decade. The percentage change in wealth is the dollar change in wealth for each individual executive divided by the total change in an executive's wealth at median firm performance, defined as the revaluation of stock and option holdings at the $50^{\text {th }}$ percentile rate of return plus salaries, bonuses, and stock option grants. Column (2) presents the median of this value across executives in each decade. Colaumn (3) approximates an elasticity of changes in wealth to changes in firm performance by dividing column (2) by the percentage difference in firm value between the $50^{\text {th }}$ and $70^{\text {th }}$ percentiles of firm performance $(22.7-8.4=14.3 \%)$. 


\section{Figure 1}

Median total compensation and its components, 1936-2005
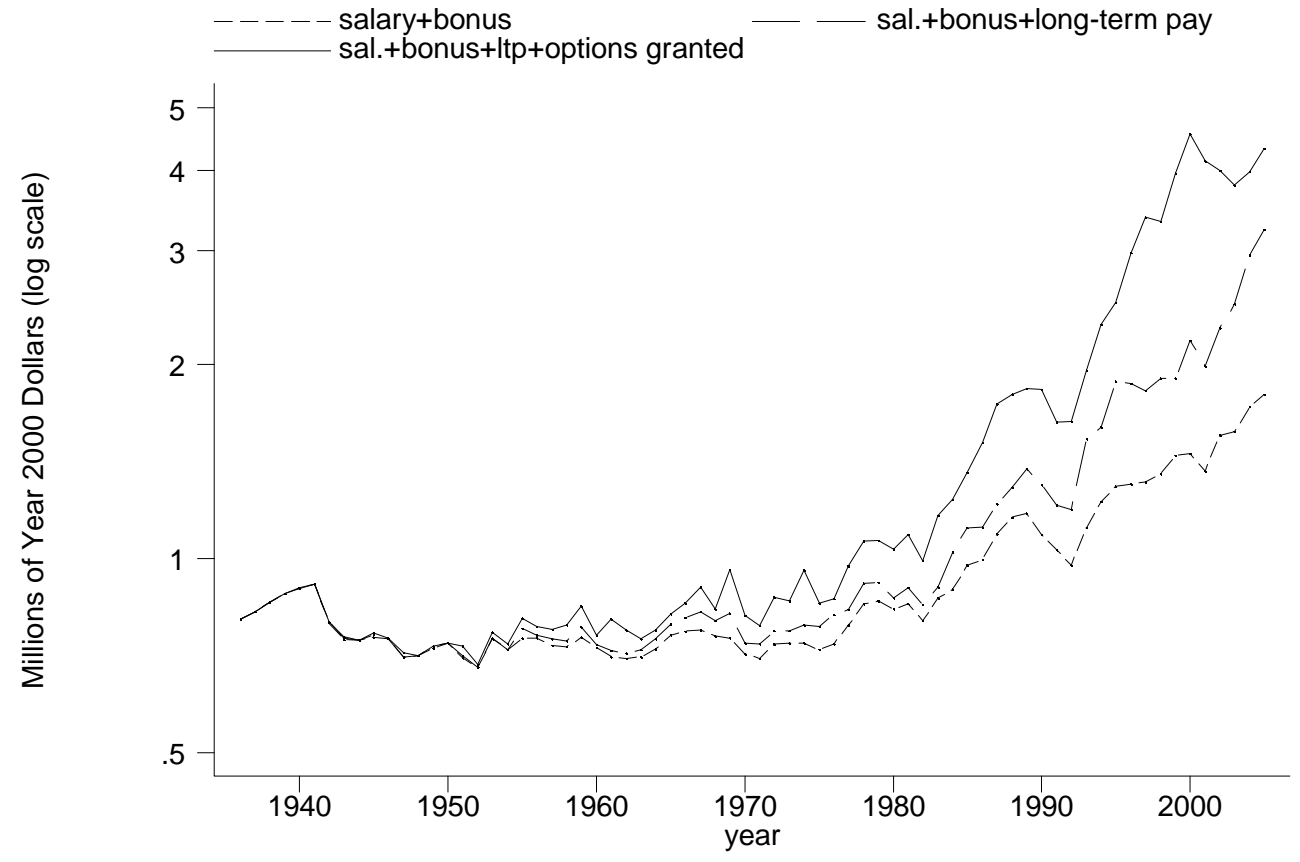

Each line shows the median value of compensation defined as an increasing number of types: salary and current bonuses (paid out in stock or in cash); salary, current bonuses, and long-term incentive payments (paid out in stock or in cash); and salary, current and long-term bonuses, and the Black-Scholes value of stock options granted. Based on the three highest-paid officers in the largest 50 firms in 1940, 1960, and 1990 (a total of 101 firms). 


\section{Figure 2 \\ Fraction of top executives granted and holding stock options}

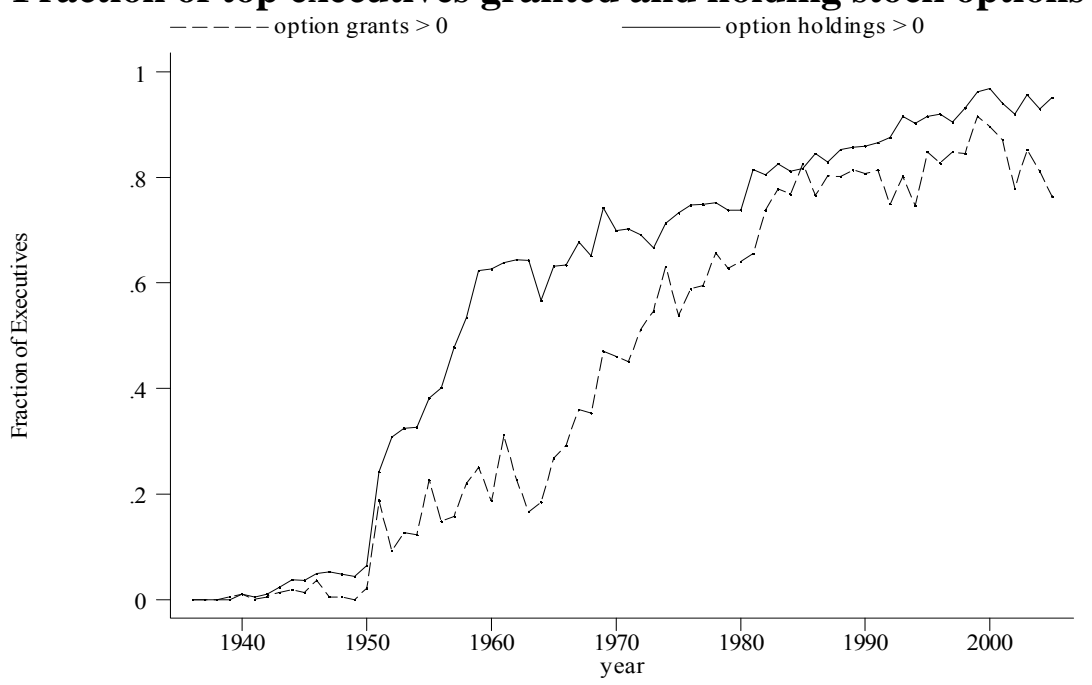

Based on the three highest-paid officers in the largest 50 firms in 1940, 1960, and 1990 (a total of 101 firms).

Option grants $>0$ shows the fraction of executives in the year that were granted at least one stock option.

Option holdings $>0$ shows the fraction of executives in the year that held at least one stock option. When not explicitly listed in proxy statements, stock option holdings are calculated based on the history of stock option grants and stock option exercises for each individual. The fraction of executives granted options includes imputations based on the cumulative number options awarded to each individual over a multi-year period. See Full Appendix Section 2.3 for details on the imputation. 


\section{Figure 3}

\section{Pre-tax and after-tax compensation}

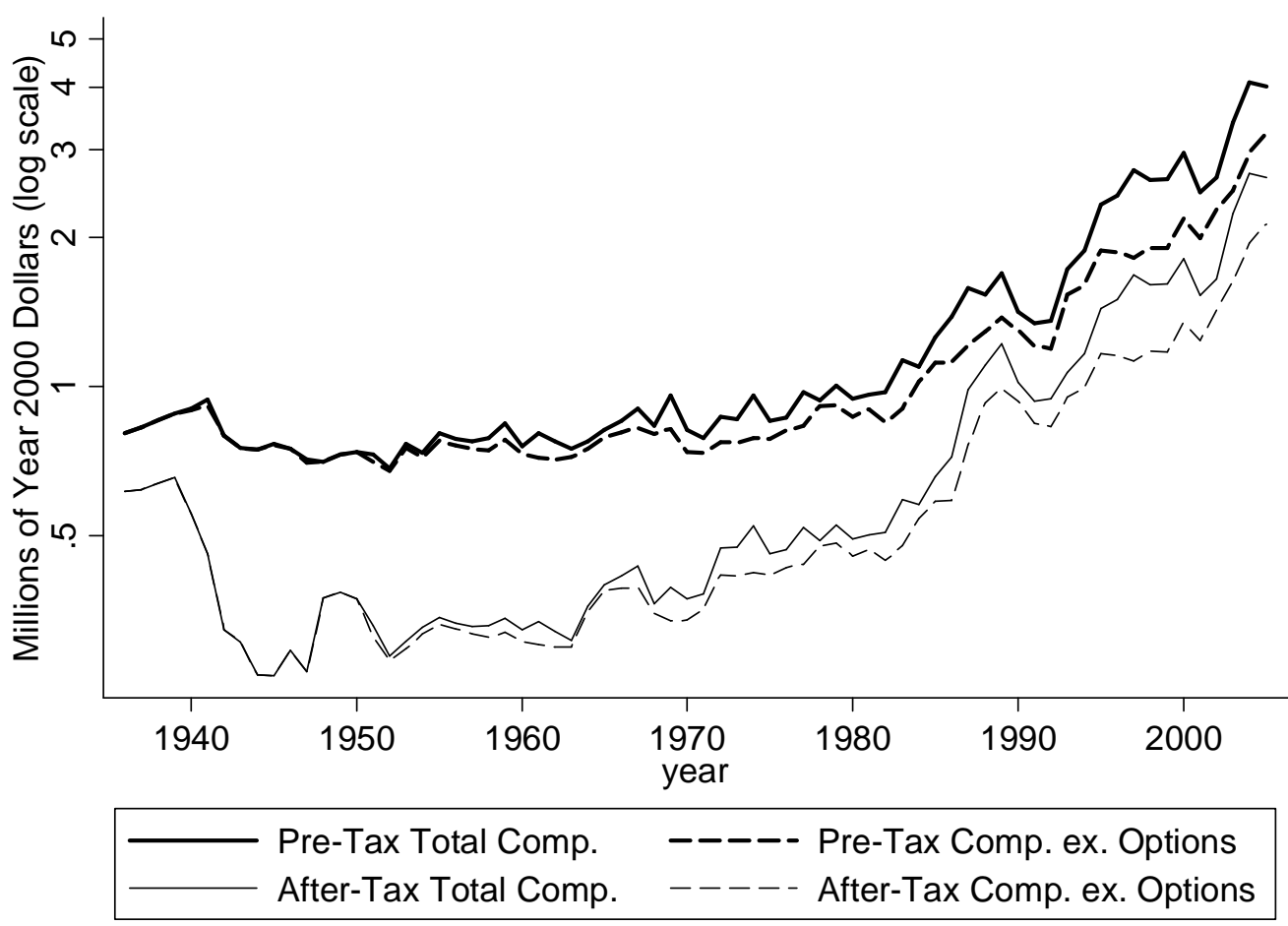

Based on the three highest-paid officers in the largest 50 firms in 1940, 1960, and 1990 (a total of 101 firms). Total compensation is composed of salary, bonuses, long-term bonus payments, and stock options. Dashed lines show the median pre-tax and after-tax compensation excluding stock options. Options values are related to how they are taxed: we use the Black-Sholes value in the year granted from 1950 to 1977 and the gains from exercising in all other years. Options are taxed as capital gains from 1950 to 1977 and as labor income in other years. After-tax pay is calculated assuming that the executive files jointly with a spouse, takes no deductions, and has no other source of income. 


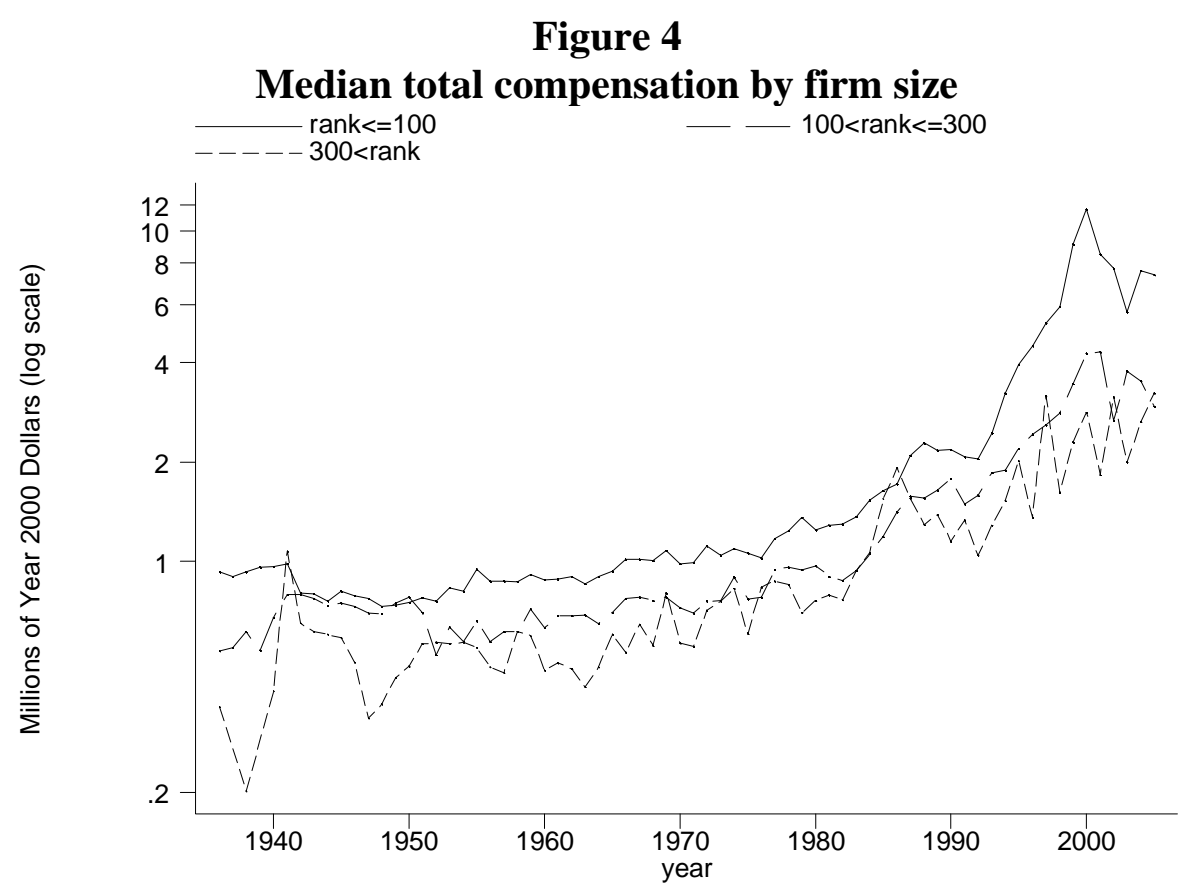

Total compensation is composed of salary, bonuses, long-term bonus payments, and stock option grants. Based on the three highest-paid officers in the largest 50 firms in 1940, 1960, and 1990 (a total of 101 firms). Rank $\leq 100$ is the median total compensation across all executives in the sample of firms ranked among the top 100 according to market value in the year; $100<$ rank $\leq 300$ is median total compensation for the executives in firms ranked 101 to $300 ; 300<$ rank is median total compensation for the executives in all firms in the sample that ranked below 300 in the year. Rankings by market value are based on all firms appearing in the CRSP database, which includes all publicly-traded firms in the NYSE, AMEX, and NASDAQ stock markets. Market value for each firm is measured at the end of the fiscal year. 


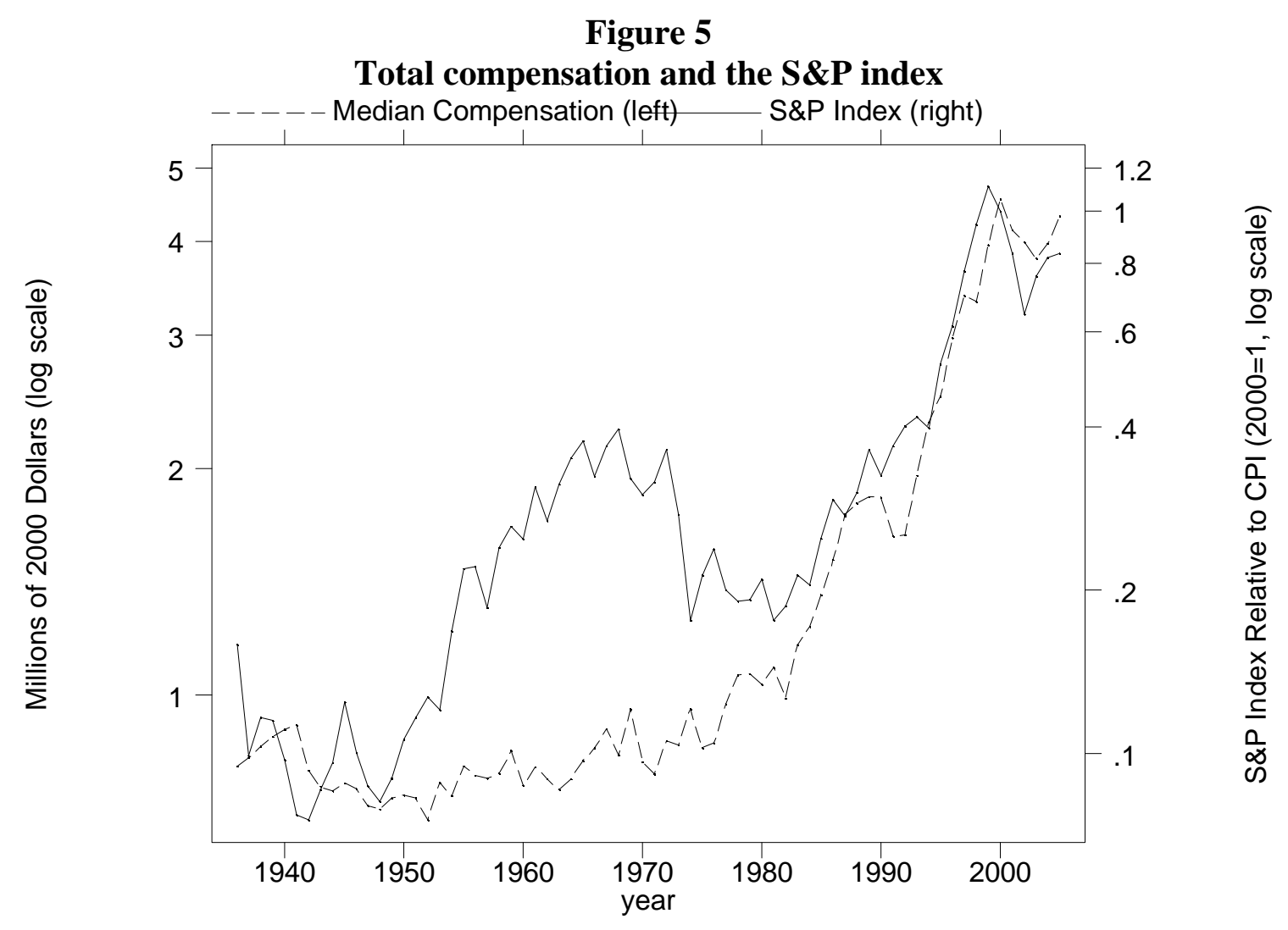

Total compensation is composed of salary, bonuses, long-term bonus payments, and stock option grants. Based on the three highest-paid officers in the largest 50 firms in 1940, 1960, and 1990 (a total of 101 firms). The S\&P index is expressed relative to the Consumer Price Index and equals 1 in 2000 . 


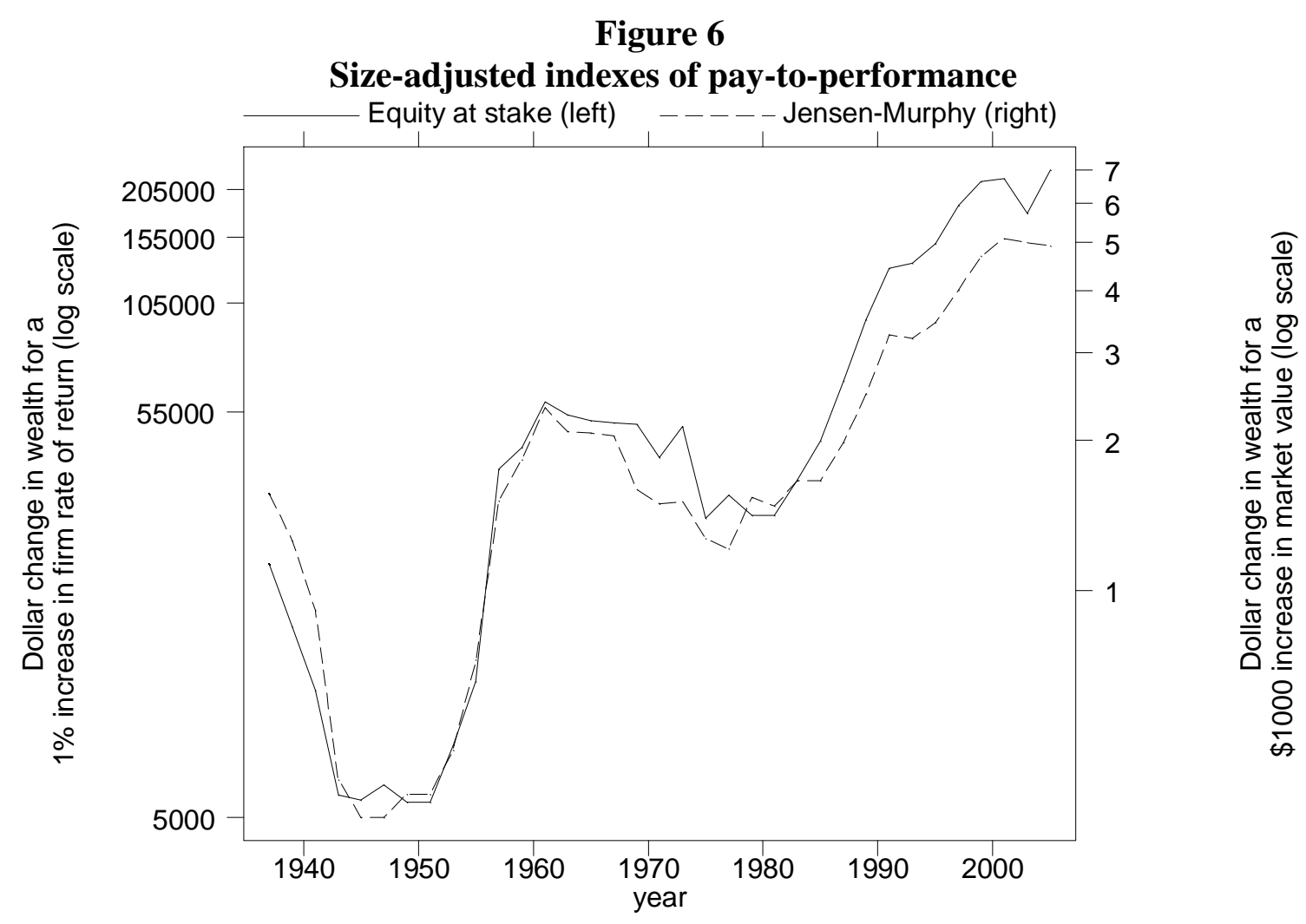

Based on the three-highest paid executives in the 50 largest firms in 1940, 1960, and 1990 (a total of 101 firms). Results are based on regressing the Jensen-Murphy statistic or value of equity at stake of each individual (which are computed from the ex-ante revaluations of stock and option holdings) on indicator variables for time and firm size in a series of overlapping 4-year sample periods. Two-year growth rates in pay-to-performance are calculated as the change in the fitted values of these regressions from the first half to the second half of the four-year sample period. The 1937 index values are equal to median pay-to-performance in 1936-1937, and changes in these indexes over time reflect the two-year change in pay-to-performance for a firm of median size. See Full Appendix Section 5 for details. 